Article

\title{
Exploring the Impact of Crises on Food Security in Lebanon: Results from a National Cross-Sectional Study
}

\author{
Maha Hoteit ${ }^{1,2}$ (D) ,oussef Al-Atat ${ }^{3}$, Hussein Joumaa ${ }^{3}$, Suheir El Ghali ${ }^{1}$, Rania Mansour ${ }^{1}$, Reem Mhanna ${ }^{1}$, \\ Fatima Sayyed-Ahmad ${ }^{1}$, Pascale Salameh ${ }^{2,4,5,6}$ (1) and Ayoub Al-Jawaldeh ${ }^{7, *} \mathbb{C}$ \\ 1 Faculty of Public Health, Lebanese University, Beirut 6573, Lebanon; m.hoteit@ul.edu.lb (M.H.); \\ suheir.ghali@ul.edu.lb (S.E.G.); rania.mansour.1@ul.edu.lb (R.M.); Reem.Mhanna@st.ul.edu.lb (R.M.); \\ fatima.sayedahmad@st.ul.edu.lb (F.S.-A.) \\ 2 Lebanese Food, Drugs and Chemical Administration, Lebanese University, Beirut 6573, Lebanon; \\ pascalesalameh1@hotmail.com \\ 3 Faculty of Science, Lebanese University, Beirut 6573, Lebanon; youssef.atat@ul.edu.lb (Y.A.-A.); \\ hussein.joumaa@ul.edu.lb (H.J.) \\ 4 Faculty of Pharmacy, Lebanese University, Beirut 6573, Lebanon \\ 5 INSPECT-LB (Institut National de Santé Publique, d'Épidémiologie Clinique et de Toxicologie-Liban), \\ Beirut 0961, Lebanon \\ 6 Department of Primary Care and Population Health, University of Nicosia Medical School, \\ 2408 Nicosia, Cyprus \\ 7 World Health Organization Regional Office for the Eastern Mediterranean, Cairo 11371, Egypt \\ * Correspondence: aljawaldeha@who.int
}

check for updates

Citation: Hoteit, M.; Al-Atat, Y.; Joumaa, H.; Ghali, S.E.; Mansour, R.; Mhanna, R.; Sayyed-Ahmad, F.;

Salameh, P.; Al-Jawaldeh, A.

Exploring the Impact of Crises on Food Security in Lebanon: Results from a National Cross-Sectional Study. Sustainability 2021, 13, 8753. https://doi.org/10.3390/su13168753

Academic Editor: Gideon Baffoe

Received: 24 June 2021

Accepted: 2 August 2021

Published: 5 August 2021

Publisher's Note: MDPI stays neutral with regard to jurisdictional claims in published maps and institutional affiliations.

Copyright: (C) 2021 by the authors Licensee MDPI, Basel, Switzerland. This article is an open access article distributed under the terms and conditions of the Creative Commons Attribution (CC BY) license (https:// creativecommons.org/licenses/by/ $4.0 /)$.

\begin{abstract}
This study aims to explore the prevalence and correlates of food insecurity among Lebanese households since the ordeals of COVID-19, economic crisis, and Beirut port explosions. At the core of the study, a mobile application entitled Nutrition Assessment System (NAS) that simplified the data collection was used as toolkit and a technical test was carried out in all Lebanese governorates between November 2020 and March 2021. Findings show that food insecurity is an immediate problem for households in Beirut and in many governorates in Lebanon. Nine in every 16 households ate less than 2 meals per day and more than $70 \%$ of them skipped their meals to spare food. Even though half the population studied had a low food consumption score, $82.4 \%$ of the people were not relying on livelihood coping strategies. However, more than three out of ten of these households relied on at least three food-based coping strategies. In addition, as for the livelihoods, this assessment found that most Lebanese households reported a drop in income along with an expansion in debt incurrence in the last 24 months to be able to buy food. Improving food security in Lebanon requires effort not only on the part of the government, but through regional and international actions.
\end{abstract}

Keywords: food security; Lebanon; nutritional assessment system; mobile; application; technology

\section{Introduction}

Food insecurity can cause a deleterious impact on all age categories. According to the 2020 State of Food Security and Nutrition in the World (SOFI) report, to the global report on food security in 2020, and to the 2020 International Food Policy Research Institute report, the COVID-19 pandemic induced chronic hunger in an additional 83 million-132 million in 2020 compared to 2019 [1]. Furthermore, according to the Global Humanitarian Overview (GHO) 2021, and the fourth Progress Report for the Global Humanitarian Response Plan (GHRP) for COVID-19 it was estimated that 265 million people warranted humanitarian assistance in 2021 [1]. It was estimated that 54.5 million people were acutely food-insecure in the Eastern Mediterranean region (EMR) due to the compounding effect of COVID-19 [2]. Moreover, an increase in food insecurity was observed in the Middle Eastern countries, where hunger has quadrupled [2]. Six out of 12 Eastern Mediterranean countries, were using in 2020, assistances as cash-based transfers and short-term assistances including 
Algeria, Libya, Tunisia, Sudan, Palestine, and Lebanon [2]. Lebanon is a small country of 10,452 square kilometers and approximately 6,855,713 million people [3] subject to heightened demographic pressures, possessing limited crop land, renewable fresh water (approximately $770 \mathrm{~m} 3$ per capita per year) [3] groundwater which accounts for $50 \%$ of irrigation water and $80 \%$ of potable water [4].

After the famine between 1915 and 1918, the political dynamics and regional and national socio-economic conditions in Lebanon were continuously influencing the agricultural development in Lebanon. In 1920, the creation of Greater Lebanon motivated the government to implement food security imperatives. Thus, to ensure that Mount Lebanon would not suffer famine again, Akkar, the Beqaa Valley, and South Lebanon-all predominantly agricultural areas-were added to Mount Lebanon. Nevertheless, this addition faced political challenges. Between 1923 and 1943, the French Mandate (1923-1943) implemented a rural development plan to gain support from rural landlords. During the rise of what became known as the "merchant republic" between 1943 and 1958, the inflow of regional capital and low-wage Palestinian refugee labor to Lebanon along with the oil boom that increased trade opportunities with the Arab Gulf states, little importance was given to take advantage of economic growth to depend economically on agriculture. In the late 1950s and early 1960s, the Chehabist reforms did not alter the system. Exportoriented agriculture and politically affiliated agro-industrial investments failed to induce any economic development. In 1975, due to the lack of rural opportunities that led to an increased migration toward Beirut and the growth of the city's poverty belt, the civil war began and ended after 15 years. Lebanon found itself, in 1990, divided into several political and territorial spaces lacking any initiative to support agriculture, and the sector relied on the intervention of international donors. In 2011, despite a lack of governmental support, the Lebanese agricultural sector adapted quickly in response to food security shocks and generated social stability and resilience in rural areas. Akkar and northern Beqaa Valley regions show the expansion of agricultural land. This local investment was based on initiative and opportunities from Lebanese people in assistant of Syrian refugee agricultural workers. Today, the financial crisis and the collapse of the Lebanese pound have aggravated the food security of vulnerable Lebanese and refugees as well [5].

Lebanon is highly reliant on food imports, as an example, more than $99 \%$ of all cereals and more than $65 \%$ of the food basket are imported [6]. Heavily indebted, Lebanon is also import dependent on the very foods that it consumes the most, such as bread and other cereals. The annual variability of production is quite pronounced, and the gap between total demand and production has continued to increase over the years [6]. Because of the extreme dependence on imports of food, agricultural and food trade balance in Lebanon is heavily in deficit. Up to $80 \%$ of the country's food needs are imported in any given year. Since 1990, the end of the civil war, governments have come and gone and policy has been shattered, not least with respect to food and nutrition security. These successive governments have adopted the behavior of borrowing, mostly from local banks [5]. Lebanon has faced multiple shocks over the past 12 months. The socioeconomic situation, political distress, the deterioration in the country's health system struggling under severe pressure because of COVID-19, the Beirut Port Explosions on 4 August which resulted in the loss of life of over 200 people, 6500 injured, 300,000 people homeless and the destruction of large parts of the city [7] altogether increased the number of households sinking into poverty, and aggravating the situation of already vulnerable communities. The financial crisis pressurized Lebanon's capacity to produce food and affected food security by increasing prices of raw materials, feed materials, pesticides, grains, and other agricultural products. Thus, the agricultural system has now fallen down, putting Lebanon's agricultural production capacity at risk. A loss of income-generating opportunities for many Lebanese was due to the pound's devaluation which has reached levels as high as 18,000 Lebanese pounds to USD 1.00. Both the impact of the financial crisis and COVID-19 confinement measures led to an inflation of $183 \%$ in the price of the food basket comprised of eight items of the Survival Minimum Expenditure Basket 
(SMEB) between October 2019 and December 2020 [8]. In the context of many challenges facing food security and agriculture in Lebanon including the Beirut port explosions, the financial and economic crisis, and the COVID-19 pandemic, and in an effort to better understand food insecurity and identify strategies for its prevention we must identify what characteristics and resources may keep families from experiencing it. Based on systems theory and findings from previous research, two research questions and two hypotheses have been formulated to guide this study. Each research question and hypothesis are summarized below.

1. Research question one: What characteristics and correlates contribute to the food insecurity of Lebanese households?

It is hypothesized that relationships will be found between many characteristics including socio-economic and socio-demographic factors in addition to the economic crisis, the Beirut port explosions, and the COVID-19 pandemic with food insecurity among Lebanese households.

2. Research questions two: What is the impact of all the previous listed factors on Lebanese households' food consumption and what are the food-based coping strategies and livelihood coping strategies followed by these households?

It is expected that households that frequently struggle from critical conditions are more at risk of food insecurity, eating unhealthy diets, and being able to eat.

To investigate these hypotheses and with the targets of Sustainable Development Goal 2 (SDG2), as well as support to the government of Lebanon and other partner efforts to eliminate food insecurity and malnutrition in the country, two strategic surveys on food security in Lebanon was conducted. The purpose of the two surveys was to meet three key objectives.

Main Objective:

- To establish a comprehensive situational analysis of Lebanon's food and nutrition security situation amid the multiple shocks facing Lebanon;

Specific Objectives:

- To identify food and nutrition security goals or targets established in national plans and at regional frameworks to facilitate progress toward zero hunger;

- To inform policy making and prioritization of interventions that would accelerate progress toward SDG target zero hunger;

Moreover, to our knowledge, there is a limited number of online digital nutrition assessment tools that accurately measure the overall nutritional situation in terms of individual or household food security during crises and the need for such a tool has been highlighted in many publications and systematic reviews [9-11]. The combination among the field of information technology, information sciences and nutrition has led to the generation of the concept to nutrition informatics [12]. This branch has become a novel approach for public health nutrition practitioners to practice in this field and make a profit for the health care [12]. According to the international telecommunication union report, published in 2020, an estimated $90 \%$ of the population had access to a mobile-broadband network (3G or above) and 4.1 billion people used the Internet in 2019, indicating a 5.3\% increase compared to 2018. In addition, in the Arab states, $91 \%$ of the population is covered by a $3 \mathrm{G}$ or higher net [13]. Today, many mobile applications, available on Google Play and Apple's online store are deliberated for the prevention and management of disease, particularly non-communicable diseases [14,15]. Rare are the mobile applications that assess food security which is one of the serious challenges and a topic of interest to academics, policy makers, practitioners, governments, and non-governmental organizations around the world and in the EMR. Thus, an innovative mobile application, entitled Nutrition Assessment System (NAS) was used to serve the above objectives. 


\section{Methodology}

Toolkit development

The goal of the developed mobile application was to provide motivation for food security assessment by examining individual or household food security status, leading to an appropriate intervention. NAS is a cloud-based platform that uses the web-based and smart technology applications. This version of NAS was developed under Java Android studio IDE. The logo of this mobile application is shown in Figure 1a. This application was initially developed for the Android (Google, Mountain View, CA, USA) system, and it will eventually be adapted for the Apple (Cupertino, CA, USA) iOS. The software engineering methods for usability, accessibility, and availability were considered in the design and implementation phases. This assessment method was validated. The software was piloted tested on a sample of more than 2000 participants. The initiative, which runs over a 2month period, assisted in the validation and development of the application by creating standard operating procedures for running this mobile application to support and to serve the public health sector. The user provides his or her personal information to use the main functions of the application. Personal information includes age, gender, height, weight, number of family members, and children per household. Height and weight are necessary information for body mass index analysis. The provided information is saved in the database and managed as user information. In any later phase, a registered user can log in automatically through a selection of a study or question. When consenting to enter the survey 1, adapted from the "Food Security and Livelihoods Assessment of Lebanese Host Communities: Assessment Report" [16] published by the food and agriculture organization (FAO) in 2015 and translated to native Arabic, were available to be answered. In addition, the questions of the second survey were adapted from a valid questionnaire published by Sahyoun et al. [17,18]. For instance, if a user selects to provide data on the survey 2 , the mobile application provides an introduction, socio-demographic questions and food security assessment questions that are appropriate for this study as shown in Figure 1b,c; subsequently, an assessment of his/her food security status starts.. When the user completes the questionnaire, this application quantifies the answers using an algorithm. Using the analyzed NAS scores, the application provides a data that was moved to Excel sheets for further analysis. The essence of this mobile application is to provide an easy and clear standard to grasp one's food insecurity level. As the questionnaire at the start of the application is based on the survey categories, it meaningfully compares the user's score with the standard. This mobile application is available and can be accessed upon request.

\subsection{Survey 1: Assessment of the Impact of Prolonged Crises on Household Food Insecurity in Lebanon}

\section{Survey design and sampling}

Covering all governorates, the Lebanese households were interviewed using this mobile application which was able to capture 1133 participants. It was a cross-sectional survey conducted between November and December 2020. The sample representativeness was then optimized by a weighting procedure, according to the Central Administration of Statistics figures of the following variables: geographical dwelling region, gender, and education level. The survey collected quantitative data on the impacts of COVID-19 and the economic crisis on people's livelihoods, coping strategies, their food security situation, through the questionnaire "Food Security and Livelihoods national assessment" [16]. This questionnaire was about $30 \mathrm{~min}$ duration and was filled through NAS in a self-administered way, after an introduction explaining the context and objectives of the survey; answering the questionnaire was an implicit informed consent. The online questionnaire included in the mobile application was available in native Arabic, the native language in Lebanon.

Variables tested

Several socio-demographic characteristics including gender, age, educational status, marital status, and number of family members were studied. Food Consumption Score 
(FCS), which is a proxy indicator used for food security analysis, was calculated using the frequency of consumption of different food groups consumed by a household during the 7 days before the survey [19]. The calculation formula of the score FCS is: (starches $\times 2)+$ $($ pulses $\times 3)+$ vegetables + fruit $+($ meat $\times 4)+($ dairy products $\times 4)+($ fats $\times 0.5)+($ sugar $\times$ 0.5) [19]. Moreover, the Coping Strategy Index (CSI) had been tested using questions about household strategies to manage coping with a food shortfall that was associated with simple numeric score [20].

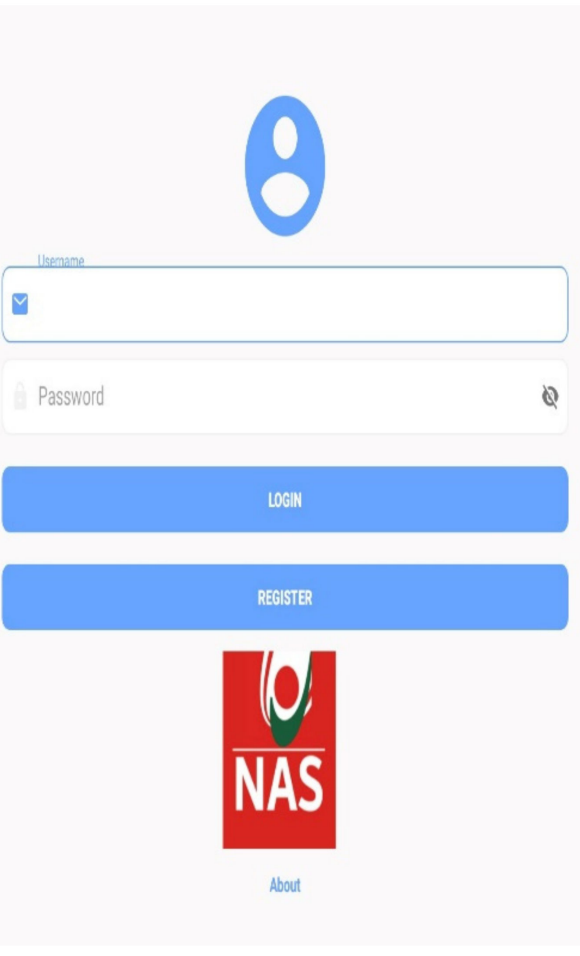

(a)

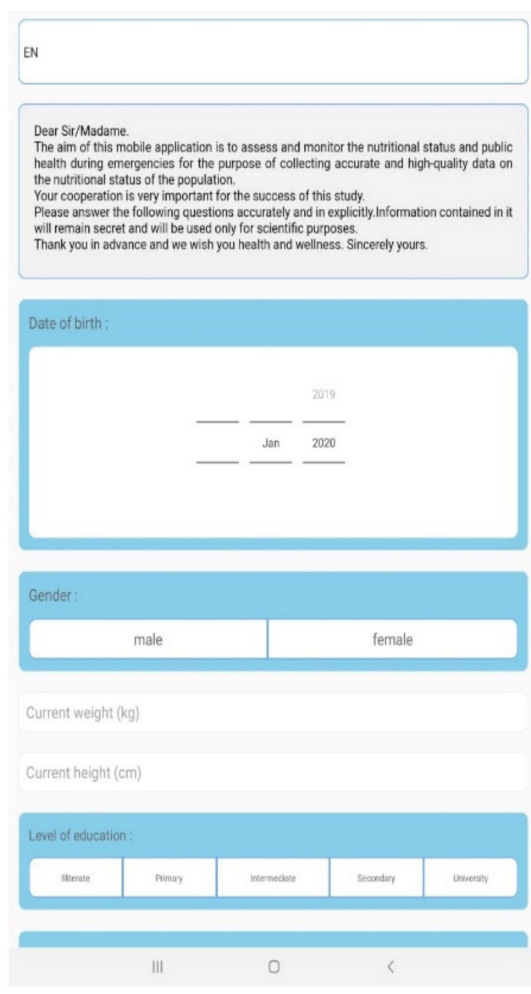

(b)

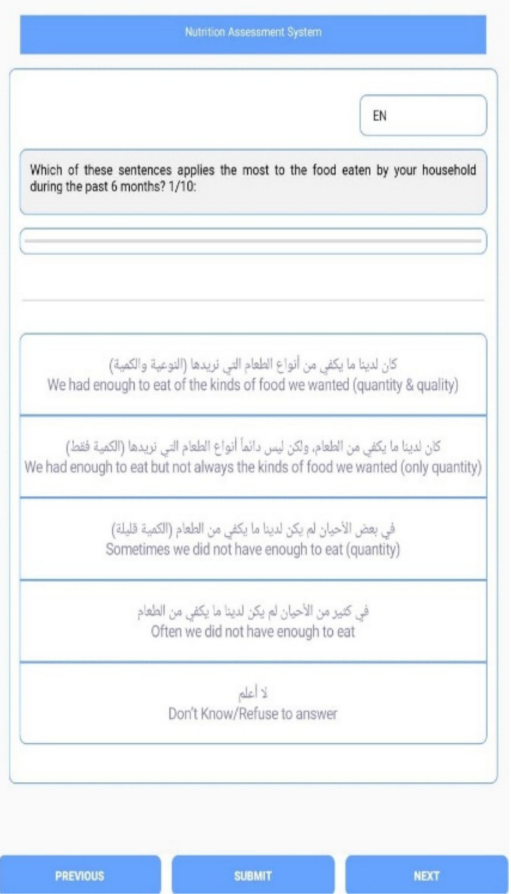

(c)

Figure 1. Application screen shots: (a) register user information and logo; (b) The introduction part and socio-demographic questions of survey 2; (c) Questions of Survey 2.

2.2. Survey 2. Assessment of the Impact of Prologned Crises on Household Food Insecurity in Areas Affected by the Beirut Port Explosions

\section{Study Sampling and Design}

This cross-sectional study was conducted between December 2020 and March 2021 using a representative random sampling of Lebanese households from Beirut province. A minimal sample size of 384 households was needed to allow for adequate power for statistical analyses to be carried out according to the Epi info sample size calculation with a total Beirut population size of 450,413 residents according to the population estimates of 2019, based on the Ministry of Public Health data, a 50\% expected frequency and a 5\% confidence limits [21]. This number was, then, multiplied by 2 to reach a representative sample of 768 households that takes cluster effect and refusals into account. A simple random selection sampling was then performed to this targeted number of households to account for all regions in Beirut and start data collection based on the number of residents obtained for each region. Even though the calculated number was a sample of 768 households, we collected more households, and we reached a total number of 1388 households. The "Arab Food Security Scales" [17,18] questionnaire was used to collect data. It was about 7 min duration and was filled through NAS in a self-administered way, after an introduction explaining the context and objectives of the survey; answering the questionnaire was an implicit informed consent. The online questionnaire included in the mobile application was also available in Arabic, the native language in Lebanon. Using this 
questionnaire, food insecurity in respondents using the scale Arab Family Food Security Scale (AFFS) and Food Insecurity Experience Scale (FIES) $[17,18]$ was assessed accordingly.

\subsection{Ethical Aspects}

The study was conducted according to the guidelines of the Declaration of Helsinki, and approved by the Ethics Committee of the Lebanese university (protocol code \#CUER 22-2020 and date of approval was on 13 May 2020). Anonymity of respondents was guaranteed throughout the process of data collection and analysis. Informed consent was obtained from all subjects involved in the study.

\subsection{Statistical Tests}

Data were converted from NAS database to Excel spreadsheet; they were then analyzed using SPSS version 26.0. A descriptive analysis was first conducted to evaluate sample characteristics. The sample size being higher than 1000, parametric tests were used in the bivariate analysis: means were compared using Student test and percentages using the Chi-squared test. A $p$-value lower than 0.05 was considered significant. A multivariate analysis was also conducted: using a binomial logistic regression, independent variables were included to explain the variability of the major dependent variable. A backward stepwise likelihood ratio method was also used. Moreover, two models were derived to optimize the probability of food insecurity.

\section{Results}

3.1. Survey 1. Assessment of the Impact of Prolonged Crises on Household Food Insecurity in Lebanon

\subsubsection{Socio-Economic Characteristics of Respondents}

The study targeted individuals above 14 years of age. Of the Lebanese respondents, and after weighting, it included $52.4 \%$ females, $19.2 \%$ university education and $73.3 \%$ school education, while $49.8 \%$ were married, and $47.1 \%$ were single (Table 1 ). The mean age of participants was 32 years $(\mathrm{SD}=12)$. For work status, $29.3 \%$ do not work (housewives and retired, mainly), $21.6 \%$ were university students, $10.8 \%$ were licensed from work and $38.4 \%$ were active workers (Table 1 ). Among current workers, $60 \%$ were healthcare workers. The current household income was inexistent for $20.1 \%$ of participants, less than USD 1000 for $45.8 \%$, USD 1000-2000 for $26.8 \%$, and more than USD 2000 for $6.9 \%$. A total of $29 \%$ were current regular smokers (Table 1). Although most households in all governorates have between 4 and 6 members, the highest number of children per family was observed only in Akkar (Appendix A). As for the financial situation, more than $40 \%$ of households in Akkar, 39\% of households in Beqaa, more than 20\% of households in North Lebanon, South Lebanon and Baalbek-El Hermel have no monthly income $(p<0.001)$ (Appendix A). Most households in all governorates have a monthly income of less than USD 1000 (Appendix A). As for chronic diseases, 20\% of respondents declared having at least one diagnosed chronic disease, where $8.5 \%$ suffer from hypertension, $4.5 \%$ from diabetes, $3.9 \%$ from anemia, $3.9 \%$ from hypercholesterolemia, $1.6 \%$ from cancer, $4.2 \%$ from chronic lung disease (asthma/chronic obstructive pulmonary disease), 6.9\% from obesity, $4.9 \%$ from depression and $8.0 \%$ from anxiety and depression (Data not shown). Women $(22.2 \%)$ were reporting more chronic diseases compared to men $(17.2 \%)(p=0.035)$ (Data not shown). 
Table 1. Socio-demographic and socio-economic characteristics of the survey respondents as overall and by gender.

\begin{tabular}{|c|c|c|c|c|c|c|c|c|}
\hline & & \multicolumn{6}{|c|}{ Gender } & \multirow[b]{3}{*}{$p$-Value } \\
\hline & \multirow[b]{3}{*}{ Age not reported } & \multirow{2}{*}{\multicolumn{2}{|c|}{$\begin{array}{c}\text { Overall } \\
\text { N (\%) }\end{array}$}} & \multirow{2}{*}{\multicolumn{2}{|c|}{$\begin{array}{c}\text { Female } \\
\text { N (\%) }\end{array}$}} & \multicolumn{2}{|c|}{ Male } & \\
\hline & & & & & & & & \\
\hline \multirow{6}{*}{ Age categories (years) } & & 132 & 11.8 & 50 & 8.4 & 82 & 15.2 & \multirow{6}{*}{0.000} \\
\hline & $14-19$ & 129 & 11.2 & 88 & 14.8 & 41 & 7.5 & \\
\hline & $20-24$ & 195 & 17.3 & 100 & 16.9 & 95 & 17.7 & \\
\hline & $25-34$ & 276 & 24.7 & 119 & 20.1 & 157 & 29.2 & \\
\hline & $35-54$ & 347 & 30.4 & 210 & 35.4 & 137 & 25.3 & \\
\hline & $55+$ & 53 & 4.8 & 26 & 4.4 & 27 & 5.1 & \\
\hline \multirow{2}{*}{ Gender } & Female & 593 & 50.0 & 593 & 100.0 & 0 & 0.0 & \multirow{2}{*}{-} \\
\hline & Male & 539 & 50.0 & 0 & 0.0 & 539 & 100.0 & \\
\hline \multirow{4}{*}{ Marital Status } & Single & 534 & 47.4 & 250 & 42.1 & 284 & 52.6 & \multirow{4}{*}{0.000} \\
\hline & Married & 563 & 49.6 & 317 & 53.4 & 246 & 45.7 & \\
\hline & Widow & 0 & 0.0 & 0 & 0.0 & 0 & 0.0 & \\
\hline & Divorced & 35 & 3.1 & 26 & 4.4 & 9 & 1.7 & \\
\hline \multirow{4}{*}{ Number of family members } & $1-3$ & 262 & 23.3 & 137 & 23.2 & 125 & 23.3 & \multirow{4}{*}{0.001} \\
\hline & $4-6$ & 753 & 66.5 & 406 & 68.5 & 347 & 64.4 & \\
\hline & $7-9$ & 98 & 8.7 & 49 & 8.2 & 49 & 9.1 & \\
\hline & More than 9 & 18 & 1.7 & 1 & 0.2 & 17 & 3.2 & \\
\hline \multirow{3}{*}{ Number of children } & None & 353 & 31.6 & 137 & 23.1 & 216 & 40.1 & \multirow{3}{*}{0.000} \\
\hline & Fewer than 3 & 523 & 46.1 & 296 & 49.9 & 227 & 42.2 & \\
\hline & More than 3 & 256 & 22.4 & 160 & 27.0 & 96 & 17.8 & \\
\hline \multirow{4}{*}{ Education } & Illiterate & 25 & 2.3 & 8 & 1.4 & 17 & 3.2 & \multirow{4}{*}{0.000} \\
\hline & Primary & 59 & 5.3 & 24 & 4.1 & 35 & 6.5 & \\
\hline & Intermediate & 830 & 73.7 & 395 & 66.6 & 435 & 80.7 & \\
\hline & University & 218 & 18.8 & 166 & 28.0 & 52 & 9.6 & \\
\hline \multirow{4}{*}{ Occupation } & Working & 434 & 39.2 & 136 & 22.9 & 298 & 55.4 & \multirow{4}{*}{0.000} \\
\hline & Fired & 122 & 11.2 & 23 & 3.9 & 99 & 18.4 & \\
\hline & Not working & 331 & 28.5 & 270 & 45.5 & 61 & 11.4 & \\
\hline & Student & 244 & 21.3 & 164 & 27.7 & 80 & 14.9 & \\
\hline \multirow{2}{*}{ Health Occupation } & Yes & 63 & 5.5 & 55 & 9.3 & 8 & 1.6 & \multirow{2}{*}{0.000} \\
\hline & No & 1069 & 94.6 & 538 & 90.7 & 531 & 98.4 & \\
\hline \multirow{4}{*}{ Smoking } & Yes & 331 & 30.1 & 69 & 11.7 & 262 & 48.5 & \\
\hline & No & 735 & 64.0 & 500 & 84.2 & 235 & 43.7 & \\
\hline & Sometimes & 52 & 4.7 & 22 & 3.8 & 30 & 5.6 & 0.000 \\
\hline & Old smoker & 14 & 1.3 & 2 & 0.3 & 12 & 2.2 & \\
\hline & No income & 227 & 20.3 & 94 & 15.9 & 133 & 24.7 & \\
\hline & less than 1.5 million LBP & 427 & 37.8 & 221 & 37.3 & 206 & 38.2 & \\
\hline & 1.5-3 million LBP & 238 & 20.9 & 140 & 23.6 & 98 & 18.2 & \\
\hline Monthly income & More than 3 million LBP & 44 & 3.9 & 30 & 5.1 & 14 & 2.6 & 0.000 \\
\hline & Less than USD 1000 & 96 & 8.6 & 50 & 8.5 & 46 & 8.6 & \\
\hline & USD 1000-2000 & 65 & 5.7 & 52 & 8.8 & 13 & 2.5 & \\
\hline & More than USD 2000 & 34 & 3.1 & 6 & 1.0 & 28 & 5.2 & \\
\hline
\end{tabular}

\subsubsection{Impact of COVID-19 on Economic Situation}

To investigate the COVID-19 impact on economic situation in Lebanon, the households were asked to assess their economic situation during the pandemic compared to the phase before and whether their ability to execute their work has been threaten as a consequence of containment measures. Around $38.3 \%$ of Lebanese respondents reported being poor since the outbreak of COVID-19 (Table 2). The percentage of respondents from both genders who reported being below the poverty line tripled from $4.6 \%$ before the pandemic to $13.5 \%$ since the outbreak (Table 2). More than $60 \%$ of respondents from both genders were afraid of poverty and according to the InCharge Financial Distress/Financial Well-Being Scale, 
used to assess the feelings of overpressure in respondents during the last 4 weeks, all respondents from all governorates were feeling overpressure concerning their financial situation (Table 2).

Table 2. Economic status, InCharge Financial Distress/Financial Well-Being Scale, depts incurrence, and assistance related to the survey's respondents by overall and according to gender.

\begin{tabular}{|c|c|c|c|c|c|c|c|c|}
\hline & & \multicolumn{6}{|c|}{ Gender } & \multirow[b]{3}{*}{$p$-Value } \\
\hline & & \multirow{2}{*}{\multicolumn{2}{|c|}{$\begin{array}{c}\text { Overall } \\
\text { N (\%) }\end{array}$}} & \multirow{2}{*}{\multicolumn{2}{|c|}{$\begin{array}{c}\text { Female } \\
\text { N (\%) }\end{array}$}} & \multicolumn{2}{|c|}{ Male } & \\
\hline & & & & & & & & \\
\hline \multicolumn{9}{|c|}{ Economic Status } \\
\hline \multirow{2}{*}{ Income change } & Yes & 327 & 28.9 & 167 & 28.1 & 160 & 29.7 & \multirow[b]{2}{*}{0.56} \\
\hline & No & 806 & 71.1 & 427 & 71.9 & 379 & 70.3 & \\
\hline \multirow{5}{*}{ Ongoing income } & Yes & 469 & 41.3 & 265 & 44.7 & 204 & 37.8 & \multirow{5}{*}{0.000} \\
\hline & Half income & 160 & 14.1 & 91 & 15.3 & 69 & 12.9 & \\
\hline & Less than half income & 78 & 7.1 & 24 & 4.1 & 54 & 10.0 & \\
\hline & Without income anymore & 427 & 37.7 & 214 & 36.0 & 213 & 39.4 & \\
\hline & Monthly income & 592 & 52.3 & 305 & 51.4 & 287 & 53.2 & \\
\hline \multirow{5}{*}{ Economic situation before COVID-19 } & Below the poverty line & 52 & 4.7 & 17 & 2.8 & 35 & 6.6 & \multirow{5}{*}{0.000} \\
\hline & Poor & 150 & 13.5 & 40 & 6.7 & 110 & 20.3 & \\
\hline & Moderate condition & 868 & 76.4 & 485 & 81.7 & 383 & 71.0 & \\
\hline & Rich & 27 & 2.4 & 16 & 2.7 & 11 & 2.0 & \\
\hline & No answer & 37 & 3.2 & 36 & 6.1 & 1 & 0.2 & \\
\hline \multirow{5}{*}{ Economic situation after COVID-19 } & Below the poverty line & 153 & 13.9 & 45 & 7.6 & 108 & 20.1 & \multirow{5}{*}{0.000} \\
\hline & Poor & 434 & 38.5 & 210 & 35.4 & 224 & 41.5 & \\
\hline & Moderate condition & 504 & 44.2 & 307 & 51.8 & 197 & 36.5 & \\
\hline & Rich & 11 & 1.0 & 2 & 0.3 & 9 & 1.7 & \\
\hline & No answer & 30 & 2.6 & 29 & 4.9 & 1 & 0.2 & \\
\hline \multicolumn{9}{|l|}{$\begin{array}{c}\text { InCharge Financial Distress/Financial } \\
\text { Well-Being Scale }\end{array}$} \\
\hline Afraid of poverty because of the & Score 1 to $5=$ Not afraid & 417 & 37.0 & 208 & 35.1 & 209 & 38.8 & \multirow{2}{*}{0.197} \\
\hline COVID-19 pandemic & score 6 to $10=$ Afraid & 715 & 63.1 & 385 & 64.9 & 330 & 61.2 & \\
\hline \multirow{2}{*}{ Financial stress } & Overpressure & 755 & 66.7 & 392 & 66.1 & 363 & 67.3 & \multirow{2}{*}{0.658} \\
\hline & Less pressure or no pressure & 377 & 33.3 & 201 & 33.9 & 176 & 32.7 & \\
\hline \multirow{2}{*}{$\begin{array}{l}\text { Satisfaction of the current } \\
\text { financial situation }\end{array}$} & Overpressure & 801 & 70.9 & 394 & 66.4 & 407 & 75.4 & \multirow{2}{*}{0.001} \\
\hline & Less pressure or no pressure & 332 & 29.1 & 199 & 33.6 & 133 & 24.6 & \\
\hline & Overpressure & 758 & 67.1 & 386 & 65.1 & 372 & 69.0 & \\
\hline Ab1lity to meet normal expenses & Less pressure or no pressure & 374 & 33.0 & 207 & 34.9 & 167 & 31.0 & 0.161 \\
\hline Payment of financial emergency amount & Overpressure & 760 & 67.1 & 399 & 67.2 & 361 & 66.9 & \\
\hline of USD 1000 & Less pressure or no pressure & 373 & 33.0 & 195 & 32.8 & 178 & 33.1 & 0.944 \\
\hline & Overpressure & 703 & 62.2 & 352 & 59.3 & 351 & 65.1 & \\
\hline Affordability of doing leisure activities & Less pressure or no pressure & 430 & 37.8 & 242 & 40.7 & 188 & 34.9 & 0.042 \\
\hline Satisfaction of financial management & Overpressure & 761 & 67.5 & 368 & 62.0 & 393 & 72.9 & \\
\hline satisfaction of financial management & Less pressure or no pressure & 371 & 32.6 & 225 & 38.0 & 146 & 27.1 & 0.000 \\
\hline Debts and assistances & & & & & & & & \\
\hline Incurred debts in the last 24 months & Yes & 613 & 54.2 & 307 & 51.7 & 306 & 56.7 & 0.092 \\
\hline & No & 519 & 45.8 & 286 & 48.3 & 233 & 43.3 & \\
\hline Amount of dept & More than or equal USD 10,000 & 45 & 4.1 & 16 & 2.7 & 29 & 5.4 & 0.001 \\
\hline & Less than USD 10,000 & 157 & 13.7 & 92 & 15.4 & 65 & 12.0 & \\
\hline & No debt & 666 & 58.7 & 360 & 60.6 & 306 & 56.7 & \\
\hline & Less than 15 million LBP & 209 & 18.5 & 109 & 18.3 & 100 & 18.6 & \\
\hline & More than or equal 15 million LBP & 56 & 5.1 & 17 & 2.9 & 39 & 7.2 & \\
\hline Duration of debt incurrence & Not reported & 519 & 45.8 & 286 & 48.3 & 233 & 43.3 & 0.000 \\
\hline & One month before & 21 & 2.0 & 3 & 0.6 & 18 & 3.3 & \\
\hline & During the last 6 months & 153 & 13.5 & 88 & 14.9 & 65 & 12.1 & \\
\hline & During the last 12 months & 153 & 13.7 & 62 & 10.5 & 91 & 16.8 & \\
\hline & During the last 24 months or more & 285 & 25.2 & 153 & 25.8 & 132 & 24.5 & \\
\hline
\end{tabular}


Table 2. Cont.

\begin{tabular}{|c|c|c|c|c|c|c|c|c|}
\hline & & \multicolumn{6}{|c|}{ Gender } & \\
\hline & & \multicolumn{2}{|c|}{ Overall } & \multicolumn{2}{|c|}{ Female } & \multicolumn{2}{|c|}{ Male } & \\
\hline & & \multicolumn{2}{|c|}{ N (\%) } & \multicolumn{2}{|c|}{ N (\%) } & \multicolumn{2}{|c|}{ N (\%) } & $p$-Value \\
\hline \multicolumn{9}{|c|}{ Economic Status } \\
\hline \multirow[t]{2}{*}{ Receiving assistance in the last 12 months } & Yes & 244 & 21.5 & 140 & 23.6 & 104 & 19.3 & 0.08 \\
\hline & No & 889 & 78.6 & 454 & 76.4 & 435 & 80.7 & \\
\hline \multirow[t]{6}{*}{ Type of assistance } & Not reported & 889 & 78.6 & 454 & 76.4 & 435 & 80.7 & 0.05 \\
\hline & Food & 166 & 14.6 & 91 & 15.4 & 75 & 13.8 & \\
\hline & Cash & 58 & 5.1 & 30 & 5.0 & 28 & 5.2 & \\
\hline & Non-food items & 0 & 0.1 & 0 & 0.0 & 0 & 0.1 & \\
\hline & Education & 18 & 1.5 & 17 & 2.8 & 1 & 0.1 & \\
\hline & Health & 1 & 0.2 & 1 & 0.2 & 0 & 0.1 & \\
\hline \multirow[t]{8}{*}{ Source of assistance } & Not reported & 889 & 78.6 & 454 & 76.5 & 435 & 80.7 & 0.001 \\
\hline & Government & 50 & 4.4 & 22 & 3.6 & 28 & 5.1 & \\
\hline & NGO & 39 & 3.5 & 20 & 3.4 & 19 & 3.6 & \\
\hline & Charity & 66 & 5.8 & 48 & 8.1 & 18 & 3.4 & \\
\hline & UN agency & 35 & 3.1 & 17 & 2.8 & 18 & 3.3 & \\
\hline & Religious organization & 12 & 1.1 & 11 & 1.9 & 1 & 0.2 & \\
\hline & Local people & 31 & 2.8 & 13 & 2.1 & 18 & 3.4 & \\
\hline & Family aboard & 11 & 1.0 & 9 & 1.6 & 2 & 0.3 & \\
\hline
\end{tabular}

When asked about taking debt or being helped financially in the past 24 months to cover basic needs, about $54.1 \%$ of Lebanese households reported incurring debts (Table 2). The highest percentage of debts was observed in Beqaa and Akkar $(p<0.001)$ (Appendix B). Debt was incurred to cover the cost of food $(37.9 \%)$, rent payments $(18.3 \%)$, education expenses $(8.3 \%)$, health expenses $(8.1 \%)$ and for investment $(8.2 \%)$ (Table 2$)$. As for assistances, the highest number of assistances were reported to Beqaa households $(41 \%)$ and the lowest to Akkar households (6.6\%) where the majority were receiving food vouchers $(14.7 \%)$ (Appendix B).

\subsubsection{Indicators of Household Food Security}

\section{Food groups consumption score}

It was observed that almost all respondents eat main food groups in a frequency of fewer than 3 days per week (Table 3). Men were consuming fewer white tubers (i.e., potatoes, onions and carrots) $(p=0.014)$, less vegetables $(p=0.045)$, less fruit $(p=0.006)$, less dairy products $(p=0.002)$, more fats and oils $(p=0.004)$, more sweets $(p=0.002)$ and more spices and condiments $(p<0.001)$ compared to women (Table 3$)$. Both genders were eating cereals, meats, eggs, pulses, nuts and fish similarly $(p>0.05)$. Most households in all governorates except in Nabatieh and South Lebanon consumed non-diversified food groups (Appendix C). According to this assessment, 53\% of the Lebanese household had a poor FCS. On the other hand, 29\% had an acceptable FCS (Table 4). Among those who had poor FCS, the highest percentage was in the age range between 20 and 54 years $(p<0.001)$ (Data not shown). Beqaa has the largest proportion of households with a poor FCS, with $83 \%$ of households calculated to have a poor FCS, followed by Akkar which sees $73 \%$ of its inhabitants with a poor FCS (Table 4). On the other hand, Nabatieh has the highest proportion of households with an acceptable FCS (more than 40\%) (Table 4). In further analyses that were not reported in this assessment, the households with poor FCS were relying mainly on cereals and vegetables. Fruit, pulses, meat, and dairy products were less consumed due to the price inflations discussed previously in this paper. On the other hand, households with acceptable FCS consumed fewer amounts of vegetable, higher amounts of fruit, pulses, meat, dairy products, sugar and fat and oils compared to those who have low FCS (Data not shown). 
Table 3. Food groups consumption per week in overall population and by gender.

\begin{tabular}{|c|c|c|c|c|c|c|c|c|}
\hline \multirow{5}{*}{ Number of meals per day one day before } & \multirow{5}{*}{$\begin{array}{l}2 \text { meals and less } \\
3 \text { meals and more }\end{array}$} & \multicolumn{6}{|c|}{ Gender } & \multirow{5}{*}{$\begin{array}{c}p \text {-Value } \\
0.146\end{array}$} \\
\hline & & \multirow{2}{*}{\multicolumn{2}{|c|}{$\begin{array}{c}\text { Overall } \\
\mathrm{N}(\%)\end{array}$}} & \multirow{2}{*}{\multicolumn{2}{|c|}{$\begin{array}{c}\text { Female } \\
\mathbf{N}(\%)\end{array}$}} & \multicolumn{2}{|c|}{ Male } & \\
\hline & & & & & & \multicolumn{2}{|c|}{$\mathbf{N}(\%)$} & \\
\hline & & 633 & 55.8 & 344 & 57.9 & 289 & 53.6 & \\
\hline & & 500 & 44.3 & 250 & 42.1 & 250 & 46.4 & \\
\hline \multirow{3}{*}{$\begin{array}{l}\text { The actual number of meals reported as } \\
\text { usual, less, or more }\end{array}$} & as usual & 813 & 71.6 & 450 & 75.8 & 363 & 67.3 & \multirow{3}{*}{0.003} \\
\hline & less than usual & 23 & 2.1 & 13 & 2.3 & 10 & 1.9 & \\
\hline & more than usual & 296 & 26.3 & 130 & 21.9 & 166 & 30.7 & \\
\hline \multicolumn{9}{|c|}{ Food groups consumption in the previous 7 days } \\
\hline \multirow{2}{*}{ Cereal } & fewer than 3 days & 788 & 69.7 & 409 & 69.0 & 379 & 70.4 & \multirow{2}{*}{0.623} \\
\hline & 4 days and more & 344 & 30.3 & 184 & 31.0 & 160 & 29.6 & \\
\hline \multirow{2}{*}{ White tubers } & fewer than 3 days & 832 & 73.7 & 418 & 70.4 & 414 & 76.9 & \multirow{2}{*}{0.014} \\
\hline & 4 days and more & 301 & 26.4 & 176 & 29.6 & 125 & 23.1 & \\
\hline \multirow{2}{*}{ Vegetable } & fewer than 3 days & 806 & 71.4 & 407 & 68.7 & 399 & 74.1 & \multirow[b]{2}{*}{0.045} \\
\hline & 4 days and more & 326 & 28.6 & 186 & 31.3 & 140 & 25.9 & \\
\hline \multirow{2}{*}{ Fruit } & fewer than 3 days & 806 & 71.3 & 401 & 67.6 & 405 & 75.0 & \multirow{2}{*}{0.006} \\
\hline & 4 days and more & 327 & 28.7 & 192 & 32.4 & 135 & 25.0 & \\
\hline \multirow{2}{*}{ Eggs } & fewer than 3 days & 942 & 83.2 & 499 & 84.1 & 443 & 82.2 & \multirow{2}{*}{0.378} \\
\hline & 4 days and more & 190 & 16.9 & 94 & 15.9 & 96 & 17.8 & \\
\hline \multirow{2}{*}{ Pulse and nuts } & fewer than 3 days & 1000 & 88.3 & 528 & 89.0 & 472 & 87.5 & \multirow{2}{*}{0.394} \\
\hline & 4 days and more & 133 & 11.8 & 65 & 11.0 & 68 & 12.5 & \\
\hline \multirow{2}{*}{ Dairy products } & fewer than 3 days & 873 & 77.3 & 436 & 73.4 & 437 & 81.1 & \multirow{2}{*}{0.002} \\
\hline & 4 days and more & 260 & 22.8 & 158 & 26.6 & 102 & 18.9 & \\
\hline \multirow{2}{*}{ Fat and oils } & fewer than 3 days & 820 & 72.6 & 408 & 68.7 & 412 & 76.4 & \multirow{2}{*}{0.004} \\
\hline & 4 days and more & 313 & 27.5 & 186 & 31.3 & 127 & 23.6 & \\
\hline \multirow{2}{*}{ Sweets } & fewer than 3 days & 871 & 77.1 & 435 & 73.3 & 436 & 80.9 & \\
\hline & 4 days and more & 262 & 22.9 & 159 & 26.7 & 103 & 19.1 & 0.002 \\
\hline & fewer than 3 days & 871 & 77.5 & 401 & 67.6 & 470 & 87.3 & \\
\hline Spices and condiments & 4 days and more & 261 & 22.6 & 192 & 32.4 & 69 & 12.7 & 0.000 \\
\hline & fewer than 3 days & 908 & 80.1 & 476 & 80.2 & 432 & 80.0 & \\
\hline Meat & 4 days and more & 226 & 19.9 & 118 & 19.8 & 108 & 20.0 & 0.955 \\
\hline & fewer than 3 days & 1070 & 94.5 & 560 & 94.3 & 510 & 94.6 & \\
\hline Fish & 4 days and more & 63 & 5.6 & 34 & 5.7 & 29 & 5.4 & 0.801 \\
\hline & 4 days and more & 152 & 31.8 & 72 & 35.9 & 80 & 27.7 & \\
\hline
\end{tabular}

Table 4. Food consumption score of respondents among governorates.

\begin{tabular}{|c|c|c|c|c|c|c|c|c|c|}
\hline FCS & $\begin{array}{c}\text { Overall } \\
(\%)\end{array}$ & Beirut (\%) & $\begin{array}{c}\text { Mount } \\
\text { Lebanon (\%) }\end{array}$ & North (\%) & $\begin{array}{c}\text { South } \\
(\%)\end{array}$ & $\begin{array}{c}\text { Beqaa } \\
(\%)\end{array}$ & $\begin{array}{c}\text { Nabatieh } \\
(\%)\end{array}$ & $\begin{array}{l}\text { Baalbek-El } \\
\text { Hermel (\%) }\end{array}$ & $\begin{array}{c}\text { Akkar } \\
(\%)\end{array}$ \\
\hline Poor & 53.0 & 53.5 & 38.8 & 58.1 & 46.9 & 83.2 & 26.1 & 26.2 & 72.9 \\
\hline Borderline & 18.4 & 17.1 & 37.3 & 4.8 & 14.0 & 3.9 & 25.6 & 48.7 & 19.3 \\
\hline Acceptable & 28.6 & 29.3 & 24.0 & 37.1 & 39.1 & 13.0 & 48.3 & 25.0 & 7.8 \\
\hline
\end{tabular}

2. Coping strategies

Coping Strategy index and livelihood coping strategies in last 30 days

The survey found that $82.1 \%$ of households had a low reliance on livelihood coping strategies in the last 30 days. However, $11.8 \%$ of the population have a medium reliance on coping strategies and 6.1\% only rely heavily on coping strategies (Table 5). At governmental level, South Lebanon, Mount Lebanon and Akkar had the biggest proportion of households that rely heavily on coping mechanisms (Appendix D). 
Table 5. CSI, livelihood coping strategies in the last 30 days and food-based coping strategies in the previous 7 days in overall population and by gender.

\begin{tabular}{|c|c|c|c|c|c|c|c|c|}
\hline & & \multicolumn{6}{|c|}{ Gender } & \multirow[b]{3}{*}{ Sig. } \\
\hline & & \multirow{2}{*}{\multicolumn{2}{|c|}{ Overall }} & \multicolumn{2}{|c|}{ Female } & \multicolumn{2}{|c|}{ Male } & \\
\hline & & & & & & & & \\
\hline \multirow{3}{*}{ CSI Categories } & Low & 930 & 82.1 & 497 & 83.8 & 432 & 80.2 & \\
\hline & Borderline & 133 & 11.8 & 71 & 12.0 & 62 & 11.6 & 0.021 \\
\hline & High & 69 & 6.1 & 25 & 4.2 & 44 & 8.2 & \\
\hline \multicolumn{9}{|c|}{ Livelihood Coping Strategies in the Last 30 days } \\
\hline \multirow{3}{*}{$\begin{array}{l}\text { In the past } 30 \text { days, spending saving to meet basic } \\
\text { food needs }\end{array}$} & Yes & 314 & 27.6 & 175 & 29.4 & 139 & 25.8 & \multirow{3}{*}{0.359} \\
\hline & No & 617 & 54.5 & 318 & 53.5 & 299 & 55.4 & \\
\hline & Done before & 202 & 17.9 & 101 & 17.0 & 101 & 18.8 & \\
\hline \multirow{3}{*}{$\begin{array}{l}\text { In the past } 30 \text { days, borrowing money to meet basic } \\
\text { food needs }\end{array}$} & Yes & 152 & 13.8 & 43 & 7.3 & 109 & 20.3 & \multirow{3}{*}{0.000} \\
\hline & No & 888 & 78.2 & 476 & 80.1 & 412 & 76.3 & \\
\hline & Done before & 93 & 8.0 & 75 & 12.6 & 18 & 3.4 & \\
\hline \multirow{3}{*}{$\begin{array}{l}\text { In the past } 30 \text { days, asking for remittances to meet } \\
\text { basic food needs }\end{array}$} & Yes & 111 & 9.9 & 57 & 9.6 & 54 & 10.1 & \multirow{3}{*}{0.219} \\
\hline & No & 960 & 84.7 & 511 & 86.1 & 449 & 83.3 & \\
\hline & Done before & 62 & 5.5 & 26 & 4.3 & 36 & 6.7 & \\
\hline \multirow{3}{*}{$\begin{array}{l}\text { In the past } 30 \text { days, spending less money on other } \\
\text { needs to meet basic food needs }\end{array}$} & Yes & 432 & 38.1 & 226 & 38.1 & 206 & 38.1 & \multirow{3}{*}{0.707} \\
\hline & No & 611 & 54.0 & 324 & 54.6 & 287 & 53.3 & \\
\hline & Done before & 89 & 8.0 & 43 & 7.3 & 46 & 8.6 & \\
\hline \multirow{3}{*}{$\begin{array}{l}\text { In the past } 30 \text { days, selling household assets to meet } \\
\text { basic food needs }\end{array}$} & Yes & 432 & 38.1 & 226 & 38.1 & 206 & 38.1 & \multirow{3}{*}{0.707} \\
\hline & No & 611 & 54.0 & 324 & 54.6 & 287 & 53.3 & \\
\hline & Done before & 89 & 8.0 & 43 & 7.3 & 46 & 8.6 & \\
\hline \multirow{3}{*}{$\begin{array}{c}\text { In the past } 30 \text { days, selling productive assets to meet } \\
\text { basic food needs }\end{array}$} & Yes & 273 & 24.4 & 100 & 16.8 & 173 & 32.0 & \multirow{3}{*}{0.000} \\
\hline & No & 803 & 70.5 & 473 & 79.7 & 330 & 61.2 & \\
\hline & Done before & 58 & 5.2 & 21 & 3.5 & 37 & 6.8 & \\
\hline \multirow{3}{*}{$\begin{array}{l}\text { In the past } 30 \text { days, taking high risk jobs to meet } \\
\text { basic food needs }\end{array}$} & Yes & 196 & 17.8 & 51 & 8.7 & 145 & 26.9 & \multirow{3}{*}{0.000} \\
\hline & No & 909 & 79.8 & 533 & 89.8 & 376 & 69.7 & \\
\hline & Done before & 27 & 2.5 & 9 & 1.6 & 18 & 3.3 & \\
\hline \multirow{3}{*}{$\begin{array}{l}\text { In the past } 30 \text { days, doing any type of labor to meet } \\
\text { basic food needs }\end{array}$} & Yes & 238 & 21.5 & 73 & 12.3 & 165 & 30.6 & \multirow{3}{*}{0.000} \\
\hline & No & 858 & 75.2 & 511 & 86.0 & 347 & 64.4 & \\
\hline & Done before & 37 & 3.4 & 10 & 1.7 & 27 & 5.1 & \\
\hline & Yes & 29 & 2.7 & 2 & 0.3 & 27 & 5.1 & \\
\hline In the past 30 days, sending adult household & No & 1077 & 95.0 & 574 & 96.7 & 503 & 93.3 & 0.000 \\
\hline & Done before & 27 & 2.4 & 18 & 3.0 & 9 & 1.7 & \\
\hline & Yes & 54 & 4.9 & 10 & 1.6 & 44 & 8.1 & \\
\hline In the past 30 days, sending children household & No & 1052 & 92.8 & 566 & 95.4 & 486 & 90.1 & 0.000 \\
\hline & Done before & 28 & 2.4 & 18 & 3.0 & 10 & 1.8 & \\
\hline & Yes & 127 & 11.1 & 81 & 13.7 & 46 & 8.5 & \\
\hline In the past 30 days, asking charity for food to meet & No & 961 & 84.9 & 494 & 83.2 & 467 & 86.6 & 0.012 \\
\hline basic food needs & Done before & 45 & 4.0 & 19 & 3.1 & 26 & 4.9 & \\
\hline & Yes & 73 & 6.6 & 20 & 3.3 & 53 & 9.8 & \\
\hline In the past 30 days, receiving E-cards from UN to & No & 1016 & 89.6 & 548 & 92.3 & 468 & 86.8 & 0.000 \\
\hline meet basic food needs & Done before & 44 & 3.9 & 26 & 4.4 & 18 & 3.4 & \\
\hline
\end{tabular}


Table 5. Cont.

\begin{tabular}{|c|c|c|c|c|c|c|c|c|}
\hline & & \multicolumn{6}{|c|}{ Gender } & \\
\hline & & \multirow{2}{*}{\multicolumn{2}{|c|}{$\begin{array}{c}\text { Overall } \\
\text { N (\%) }\end{array}$}} & \multirow{2}{*}{\multicolumn{2}{|c|}{$\begin{array}{c}\text { Female } \\
\mathbf{N}(\%)\end{array}$}} & \multicolumn{2}{|c|}{ Male } & \\
\hline & & & & & & \multicolumn{2}{|c|}{$\mathbf{N}(\%)$} & Sig. \\
\hline \multicolumn{9}{|c|}{ Food-based coping strategies in the previous 7 days } \\
\hline \multirow[t]{2}{*}{ Eating cheaper foods } & fewer than 3 days & 480 & 76.6 & 210 & 76.4 & 270 & 76.7 & \\
\hline & 4 days and more & 147 & 23.5 & 65 & 23.6 & 82 & 23.3 & \\
\hline \multirow[t]{2}{*}{ Borrowing food } & fewer than 3 days & 249 & 82.1 & 96 & 79.0 & 153 & 85.2 & \\
\hline & 4 days and more & 53 & 17.9 & 26 & 21.0 & 27 & 14.8 & \\
\hline \multirow{2}{*}{ Eating less meals to spare food for children } & fewer than 3 days & 408 & 74.0 & 169 & 73.2 & 239 & 74.7 & \\
\hline & 4 days and more & 143 & 26.1 & 62 & 26.8 & 81 & 25.3 & \\
\hline \multirow[t]{2}{*}{ Eating small amounts } & fewer than 3 days & 380 & 74.8 & 158 & 71.9 & 222 & 77.6 & \\
\hline & 4 days and more & 126 & 25.3 & 62 & 28.1 & 64 & 22.4 & \\
\hline \multirow[t]{2}{*}{ Adults only eat less to spare food for children } & fewer than 3 days & 337 & 68.2 & 128 & 64.1 & 209 & 72.3 & \\
\hline & 4 days and more & 152 & 31.8 & 72 & 35.9 & 80 & 27.7 & \\
\hline
\end{tabular}

One in two Lebanese households resorted to severe crisis or emergency livelihood coping strategies including spent savings $(27.7 \%)$, selling household $(38.1 \%)$ and practices assets $(24.1 \%)$. It was observed that women were coping with lack of food by asking charities to provide assistances compared to men $(p=0.012)$ who borrowed money, sold productive assets, took high risk labor or any type of labors to meet basic food needs (Table 5).

Food-based coping strategies in the previous 7 days

In the last 7 days, $23.5 \%$ of households, reported eating cheaper food in more than 4 days per week (Table 5). Moreover, $17.3 \%$ of households borrowed foods or received assistances, and more than $25 \%$ ate less meals and less portions and sizes in the last week of response. In addition, more than $30 \%$ of the respondents reported eating less to spare food for their children (Table 5). This latter was remarked mainly in women (35.9\%) compared to men $(27.7 \%)(p=0.05)$. Baalbek-El Hermel had the biggest percentage of people relying on coping strategies in frequency of 4 days and more per week (Appendix D).

Food-based coping strategies in the previous 30 days

Nearly 9 in every 16 households were eating less than 2 meals per day while more than $70 \%$ of them considered this pattern as "usual pattern" (Table 5). Furthermore, apparent large percentages $(70 \%)$ of the respondents from all governorates reported skipping their meals to spare food in the 30 last days. Moreover, $13.7 \%$ were worried about not having enough to eat, $5.4 \%$ were unable to eat healthy food and $7 \%$ ate few kinds of foods. Furthermore, $5 \%$ ate less, spend their days not eating the whole day and staying hungry (Figure 2).

3. Sources of drinking water and planting crops

A majority (40\%) of households were drinking water from market stores and no one reported drinking water from municipal connection. Half the women were buying water from market stores compared to $31 \%$ men $(p<0.001)$ (Data not shown). Even though most of the respondents (more than $60 \%$ ), were interested in planting crops, and $62 \%$ of them requested training in agricultural production, only $23 \%$ of respondents were planting crops except for Nabatieh and Baalbek-El Hermel $(p<0.001$ ) (Data not shown). Almost all $75 \%$ of the crops were consumed by the household itself and $25 \%$ were bought to increase monthly income or freely given for community support (Data not shown).

\section{Physical access to food: Markets, shopping behaviors, and food stocks}

Market accessibility is an important indicator to physical access of food. To evaluate the access to markets, this assessment asked Lebanese households about the markets accessed to purchase food, transportation tool they use to travel there, and the duration to reach these markets. Nearly $68 \%$ of households all over Lebanon access local shops to 
purchase food and only $17.1 \%$ access open air markets. A total of $85 \%$ of the respondents need around $30 \mathrm{~min}$ to access food markets and around half the respondents use cars to reach markets. Only $28.5 \%$ walk on feet. People who plant crops were asked about the place of selling their products; the majority $38.2 \%$ sell their crops at the marketplaces and around $12 \%$ sell at farms and agriculture cooperatives (Data not shown).

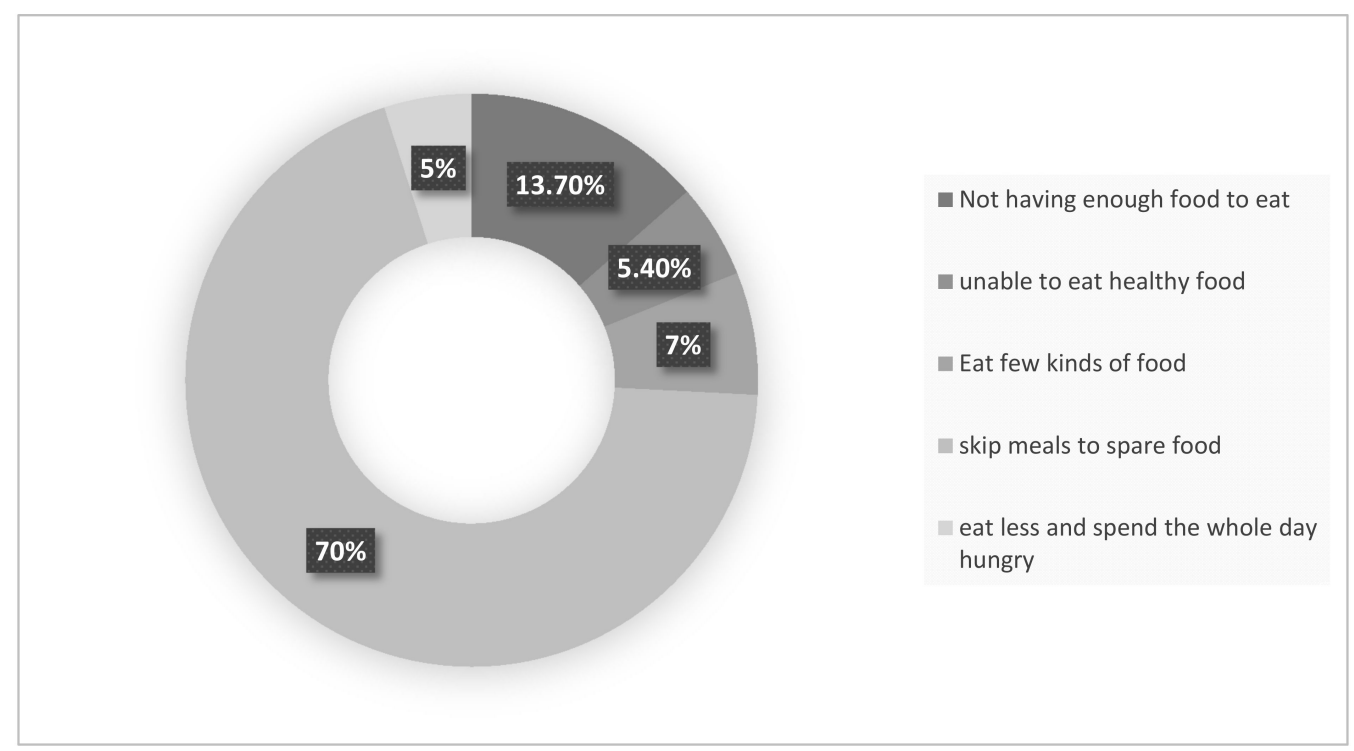

Figure 2. Food-based coping strategies in last 30 days.

\subsubsection{Correlates of Household Food Insecurity}

The binary logistic regression model shows the relationship between several independent variables and the dependent variables FCS and CSI. Initially, 10 variables were introduced to the model for both FCS and CSI. Subjects were then grouped into 3 categories (poor, borderline, and high) based on their calculated FCS and CSI as follows: fewer than 28 , between 28-42, more than 42 for FCS, and fewer than 18.6, between 18.6-37.5 and more than 37.5 for CSI, respectively. Other subgroups were also analyzed according to the following subgroups: acceptable FCS $(\geq 42)$ versus unacceptable FCS $(<42)$ and acceptable CSI $(\geq 37.5)$ versus unacceptable CSI $(<37.5)$.

\section{Food consumption score}

According to Table 6, many factors were affecting the FCS of the Lebanese households of which: age, place of living, number of children, incurring debts, planting crops, the time needed to access the market, education, and monthly income. As per the binary logistic analyses, it was shown that older participants heading the household have lower FCS compared to youngers. Those between 35 to 54 years showed 96\% less FCS compared to participants between 14 and 19 years old (OR $=0.03,95 \%$ CI [0.19, 0.67]). Similarly, the head of households with age range between 25 and 34 years showed $49 \%$ less FCS than those between 14 and 19 years (OR $=0.50,95 \%$ CI [0.270, 0.949]). The FCS of university educated participants, heading the households, was 2.4-fold higher than the FCS of people who did not attend colleges and universities ( $\mathrm{OR}=2.3,95 \% \mathrm{CI}[1.59,3.48])$. Additionally, households in South presented 65\% less FCS compared to those residing in Akkar $(\mathrm{OR}=0.34,95 \% \mathrm{CI}[0.16,0.72])$. It was shown that households who have not yet children had 1.8 times higher FCS compared to those with fewer than 3 children (OR $=1.83,95 \%$ CI $[1.26,2.65])$. In addition, those with more than 3 children had 4 times higher FCS compared to the households with fewer than 3 children (OR $=4.2,95 \%$ CI $[2.5,6.6])$. Moreover, it was shown that households who incurred debts in the previous 24 months, spent their money on buying food and had 2.7-fold higher FCS compared to those who did not incurred debts $(\mathrm{OR}=2.72,95 \% \mathrm{CI}[1.93,3.82])$. Respondents who lived far from market and spend more than $1 \mathrm{~h}$ to reach it had 91\% lower FCS compared to those who lived nearby (OR $=0.09$, 
$95 \%[0.01,0.58])$. In addition, people who had an income of less than 3 million Lebanese pounds (equivalent to USD 234) and more than 3 million Lebanese pounds had a lower FCS ranging between $87 \%$ and $52 \%$ lower than those who had an income of more than USD 2000, respectively.

Table 6. Backwards Odds ratios (OR) according to food consumption score (borderline is merged with poor category).

\begin{tabular}{|c|c|c|c|c|}
\hline \multicolumn{5}{|c|}{ Food Consumption Score } \\
\hline \multirow{2}{*}{ Food Security Correlates } & \multirow{2}{*}{ OR } & \multicolumn{2}{|c|}{ 95\% C.I. for EXP(B) } & \multirow[t]{2}{*}{$p$-Value } \\
\hline & & Lower & Upper & \\
\hline Age Categories & & & & $<0.001$ \\
\hline 55 + vs. [14-19] & 0.038 & 0.197 & 0.745 & 0.005 \\
\hline$[35-54]$ vs. $[14-19]$ & 0.036 & 0.199 & 0.671 & 0.001 \\
\hline [25-34] vs. [14-19] & 0.507 & 0.270 & 0.949 & 0.034 \\
\hline$[20-24]$ vs. $[14-19]$ & 0.629 & 0.247 & 1.606 & 0.333 \\
\hline Education & & & & $<0.001$ \\
\hline University educated vs. non-university educated & 2.354 & 1.590 & 3.484 & $<0.001$ \\
\hline Place of Living & & & & 0.001 \\
\hline Beirut vs. Akkar & 0.721 & 0.342 & 1.520 & 0.391 \\
\hline Mount Lebanon vs. Akkar & 1.007 & 0.420 & 2.412 & 0.988 \\
\hline North vs. Akkar & 0.631 & 0.258 & 1.543 & 0.313 \\
\hline South vs. Akkar & 0.345 & 0.163 & 0.727 & 0.005 \\
\hline Bekaa vs. Akkar & 1.213 & 0.343 & 4.289 & 0.765 \\
\hline Nabatieh vs. Akkar & 0.724 & 0.167 & 3.138 & 0.666 \\
\hline Baalbeck vs. Akkar & 0.374 & 0.132 & 1.062 & 0.065 \\
\hline Number of Children & & & & $<0.001$ \\
\hline 0 children vs. having fewer than 3 children & 1.835 & 1.266 & 2.659 & 0.001 \\
\hline $\begin{array}{c}\text { Having more than } 3 \text { children vs. having fewer than } 3 \\
\text { children }\end{array}$ & 4.212 & 2.558 & 6.639 & $<0.001$ \\
\hline Incurring debts & & & & $<0.001$ \\
\hline Incurring debts vs. not incurring & 2.721 & 1.937 & 3.824 & $<0.001$ \\
\hline Time to reach market & & & & \\
\hline more than $1 \mathrm{~h}$ vs. less than $1 \mathrm{~h}$ & 0.093 & 0.015 & 0.588 & 0.12 \\
\hline Income & & & & $<0.001$ \\
\hline no income vs. more than USD 2000 & 0.281 & 0.170 & 0.465 & $<0.001$ \\
\hline less than 3 million vs. more than USD 2000 & 0.126 & 0.053 & 0.298 & $<0.001$ \\
\hline more than 3 million vs. more than USD 2000 & 0.481 & 0.254 & 0.909 & 0.024 \\
\hline less than USD 2000 vs. more than USD 2000 & 0.114 & 0.042 & 0.305 & $<0.001$ \\
\hline
\end{tabular}

2. Coping strategy index

The investigation, through binary logistic regression, of the correlates affecting CSI in the survey's respondents showed rare significance of almost all the factors studied in relation to CSI except for the factors "number of family members" "debts incurrence" and "receiving assistances". Households in which family members incurred debts and assistances were coping more than 10-fold higher than those who did not $(\mathrm{OR}=14.212$, 95CI [1.85, 109.10]) and (OR 12.1, 95\% CI [1.20, 122.4]), respectively. In addition, households with more than 3 children were coping 20 times more compared to those with fewer than 3 children $(\mathrm{OR}=20.7,95 \%$ CI $[1.73,248.1])$.

3.2. Survey 2. Assessment of the Impact of Prologned Crises on Household Food Insecurity in Areas Affected by the Beirut Port Explosions

3.2.1. Socio-demographic Characteristics of the Study Population

A sample of 1388 respondents was reached. It includes $52.5 \%$ females, $70.5 \%$ school education, while $10.3 \%$ were illiterate. A total of $72.7 \%$ were married, and the majority $(76.1 \%)$ have more than 4 family members and fewer than 3 children $(74.6 \%)$ in the same household. The mean age of respondents was 41.5 years $(\mathrm{SD}=14.2)$. Concerning work status, $20.1 \%$ were active workers where only $7.7 \%$ worked in the health sector, $43.7 \%$ do not work (housewives and retired), and 31.5\% were licensed from work. 
Almost all the respondents were current smokers and around 1.9\% of alcohol drinker consume more than 1 cup per day. Among participants, $88.8 \%$ declared being severely affected, as households, by the Beirut Port Explosions on August 4, 2020 (Table 7).

Table 7. Socio-demographic and socio-economic characteristics of the survey respondents as overall and by gender.

\begin{tabular}{|c|c|c|c|}
\hline & & $\mathbf{N}$ & $\%$ \\
\hline \multirow[b]{2}{*}{ Gender } & Female & 729 & 52.5 \\
\hline & Male & 659 & 47.5 \\
\hline \multirow{5}{*}{ Education } & Elementary & 445 & 32.1 \\
\hline & High school & 224 & 16.1 \\
\hline & Illiterate & 143 & 10.3 \\
\hline & Primary & 310 & 22.3 \\
\hline & University & 266 & 19.2 \\
\hline \multirow{4}{*}{ Marital status } & Divorced & 74 & 5.3 \\
\hline & Married & 1009 & 72.7 \\
\hline & Single & 239 & 17.2 \\
\hline & Widowed & 66 & 4.8 \\
\hline \multirow{2}{*}{ Family members } & 3 and less & 332 & 23.9 \\
\hline & 4 or more & 1056 & 76.1 \\
\hline \multirow{2}{*}{ Number of children } & 3 or less & 1030 & 74.6 \\
\hline & 4 and more & 350 & 25.4 \\
\hline \multirow{2}{*}{ Number of rooms } & 3 and less & 1152 & 83.0 \\
\hline & 4 and more & 236 & 17.0 \\
\hline \multirow{4}{*}{ Occupation } & Fired & 437 & 31.5 \\
\hline & House-wife/men & 607 & 43.7 \\
\hline & Student & 65 & 4.7 \\
\hline & Working & 279 & 20.1 \\
\hline \multirow{2}{*}{ Health field } & No & 1281 & 92.3 \\
\hline & Yes & 107 & 7.7 \\
\hline \multirow[t]{4}{*}{ Medical insurance } & No health insurance & 987 & 71.1 \\
\hline & Other public insurance & 34 & 2.4 \\
\hline & Private insurance & 41 & 3.0 \\
\hline & Social security & 326 & 23.5 \\
\hline \multirow[t]{3}{*}{ Alcohol } & 0 cups per day & 1361 & 98.1 \\
\hline & less than 2 cups per $\mathrm{d}$ & 24 & 1.7 \\
\hline & more than 2 cups per $d$ & 3 & 0.2 \\
\hline \multirow[t]{4}{*}{ Cigarette } & Non smoker & 0 & 0.0 \\
\hline & $1-10$ & 946 & 68.2 \\
\hline & $10-30$ & 311 & 22.4 \\
\hline & more than 30 & 131 & 9.4 \\
\hline \multirow[t]{2}{*}{ Blast } & No & 155 & 11.2 \\
\hline & Yes & 1233 & 88.8 \\
\hline
\end{tabular}

\subsubsection{Food Insecurity Experience Scale}

Using the scale Arab Family Food Security Scale (AFFSS), the majority $(75.4 \%)$ of households were severely food-insecure. Similarly, the majority (43\%) of respondents also were shown to be severely food-insecure, using Food Insecurity Experience Scale (FIES). Using both scales AFFSS and FIES, more than $60 \%$ of people (heading households) were food-insecure, and the highest percentage of food insecurity was observed in the age category between 14 and 47 years (youth group). The survey respondents were asked about the most appropriate sentence describing the household status during the previous 6 months. A total of $31 \%$ of households were consuming what they want to consume in 
enough quantity. On the other hand, the same percentage of people were also consuming enough quantity of food but not as they want. Furthermore, there was a percentage of households, in a range between $3 \%$ and $9 \%$, who did not have enough to eat. The same result was observed also when asking the head of each household men and women each alone (Appendix E). The results of the Pearson correlation analysis used to investigate the association between food insecurity and the factors studied showed that any factors influenced the food security status of these households affected by the Beirut explosions including the number of family members, the number of children in each household, education, and occupation as presented in Table 8.

Table 8. Factors affecting the food security status of the study population.

\begin{tabular}{|c|c|c|c|c|c|}
\hline \multicolumn{6}{|c|}{ Pearson Chi-Square Tests } \\
\hline & & Family Members & Number of Children & Education & Occupation \\
\hline $\begin{array}{l}\text { Which of these sentences applies the most to the } \\
\text { food eaten by your household in the past } 6 \text { months? }\end{array}$ & Sig. & 0.038 & 0.056 & 0.000 & 0.000 \\
\hline $\begin{array}{l}\text { In the last } 6 \text { months, was there a time when you } \\
\text { were concerned that you would run out of food for } \\
\text { your household for the next month? }\end{array}$ & Sig. & 0.069 & 0.001 & 0.000 & 0.000 \\
\hline $\begin{array}{l}\text { Did the following statement apply to your } \\
\text { household in the last } 6 \text { months? "The food that we } \\
\text { bought was not enough and we didn't have money } \\
\text { to get more." }\end{array}$ & Sig. & 0.107 & 0.066 & 0.000 & 0.000 \\
\hline $\begin{array}{l}\text { Are there any foods you feel your family does not } \\
\text { eat enough of? }\end{array}$ & Sig. & 0.116 & 0.023 & 0.000 & 0.000 \\
\hline $\begin{array}{c}\text { In the past } 6 \text { months, did you or any other adult in } \\
\text { your household ever cut the size of your meal } \\
\text { because there was not enough food? }\end{array}$ & Sig. & 0.349 & 0.113 & 0.000 & 0.000 \\
\hline $\begin{array}{l}\text { In the past } 6 \text { months, did you or any other adult ever } \\
\text { skip a meal because there was not enough food? }\end{array}$ & Sig. & 0.102 & 0.007 & 0.000 & 0.000 \\
\hline $\begin{array}{l}\text { In the past } 6 \text { months did you or any adult in your } \\
\text { household not eat for a whole day or go to bed } \\
\text { hungry because there was not enough food? }\end{array}$ & Sig. & 0.279 & 0.002 & 0.000 & 0.000 \\
\hline $\begin{array}{c}\text { During the last } 6 \text { months, was there a time when you } \\
\text { or any adult in your household were unable to eat } \\
\text { healthy and nutritious food because of a lack of } \\
\text { money or other resources? }\end{array}$ & Sig. & 0.758 & 0.305 & 0.000 & 0.000 \\
\hline $\begin{array}{l}\text { During the last } 6 \text { months, was there a time when you } \\
\text { or any adult in your household were hungry but did } \\
\text { not eat because there was not enough money or } \\
\text { other resources for food? }\end{array}$ & Sig. & 0.159 & 0.000 & 0.000 & 0.000 \\
\hline $\begin{array}{c}\text { During the last } 6 \text { months, was there a time when you } \\
\text { or any adult in your household went without eating } \\
\text { for a whole day because of a lack of money or } \\
\text { other resources? }\end{array}$ & Sig. & 0.321 & 0.020 & 0.000 & 0.000 \\
\hline
\end{tabular}

\section{Discussion}

Food insecurity can change over time for a variety of reasons. Between 1914 and 1918, as the First World War raged across Europe and beyond, a dark chapter unfolded in what was then known as Greater Syria. During this period, food shortages were so severe that civilians in the Ottoman territories saw their cost-of-living rise to unprecedented levels and at a much higher rate than civilians in for example Paris, London, and Berlin. For example, the price of wheat in Beirut, according to one account, rose from by a factor of eight from five ghurūsh per roṭl in February 1916 to forty ghurūsh in November of the same year, whereas in Paris and London prices doubled and tripled in Berlin [5].In fact, the crisis of civilian provisioning in some regions of the empire-urban Beirut and rural Mount Lebanon most notably - escalated into a fully fledged famine; a famine so cruel and relentless that it would dominate the memory of World War I as the "war of famine" for generations. Indeed, 
the effects of the "war of famine" were so severe that by its end in 1918, all that seemed to have been left were cities filled with starving refugees and villages emptied of their young men if not all their residents and drained of their political opposition and exhausted from hunger. This marked the beginning of a period that is now often just a footnote in the history books: the Great Famine of 1915-1918, which left an estimated 500,000 people dead. With a lack of accurate data, estimates range from 100,000 to 200,000 deaths in Mount Lebanon alone. At this time, the population of Lebanon was estimated at about 400,000, meaning that half its people died. It is perhaps imprecise to say that capitalism 'caused' the famine. The crisis happened because the interests of French industrial capital and the local bourgeoise dominated Lebanese social organization. In that regard, it was an exception in the rural Ottoman Empire. Lebanon's tragedy can only be explained regarding capitalism's proclivity for producing crises in the human relationship with the rest of the environment. In 1920, the implementation of food insecurity came hand by hand with the creation of Greater Lebanon. Thus, to ensure that Mount Lebanon would not suffer famine again, Akkar, the Beqaa Valley, and South Lebanon —all predominantly agricultural areaswere added to Mount Lebanon. Nevertheless, this addition faced political challenges. Since 1947 (Palestinian war), passing by 2003 (Iraqi war) and 2011 (Syrian war), Lebanon hosts the largest number of Syrian refugees per capita, with a government estimate of 1.5 million Syrian refugees. It also hosts an additional 18,500 refugees from Ethiopia, Iraq, Sudan, and other countries, as well as more than 200,000 Palestinian refugees under UNRWA's mandate [22]. The influx of such high numbers of displaced people has had a serios impact on the political and socio-economic situation in Lebanon, contributing to increased instability. Displaced populations were competing with Lebanese citizens for jobs, markets, public services, and infrastructure mainly for already scarce and fragile natural resources such as land, water, and forests. Increased competition between local workers and displaced populations resulted in reduced household incomes among host communities. In addition, decreases in wages and increases in expenditures are also potential threats to the food security situation of host communities. All these issues together pushed poor and very poor households of the host communities into asset depletions, poverty, and increased vulnerability to future shocks. The impact of the Palestinian and Syrian crises on Lebanon's rural economy and agriculture sector is another concern. Since the end of the civil war in 1990, the political tempo has been high; governments have come and gone and policy has been fragmented, not least with respect to food and nutrition security. Tax bases have remained low while successive governments have adapted to spending requirements through borrowing, mostly from local banks. The political turmoil has resulted in economic growth not keeping pace with rising debt which now stands as one of the highest in the world compared to the gross domestic product. Partially as a result, social safety nets remain underdeveloped, and the poverty rate has remained high. Heavily indebted, Lebanon is also import dependent on the very foods that it consumes the most, such as bread and other cereals. In addition, while it can maintain a reasonably sufficient supply of food, economic access to food and nutrition creates a raft of issues, especially during price shocks. To our knowledge, and since the ordeals of COVID-19, economic crisis, and the Beirut port explosions, the present study is the first to inspect the prevalence and correlates of food insecurity among a representative sample of Lebanese households. Findings show that food insecurity is an immediate problem for households in Beirut and in many governorates in Lebanon. Between November 2020 and March 2021, 9 in every 16 households ate less than 2 meals per day and more than $70 \%$ of them skipped their meals to spare food. These findings were higher than the results reported by the WFP report published in June 2020, prior to the Beirut explosions, in which 19\% of households used to skip meals or stay hungry all days or nights. Even though half the population studied had a low FCS, $82.4 \%$ of the people were not relying on livelihood coping strategies. However, more than three out of ten of these people relied on at least three food-based coping strategies. In the present study, the number of people whose FCS was poor (53\%) was found to be higher compared to those reported previously in 2015 (11.1\%) [18] and higher 
than those reported in other middle-income countries in the MENA region, including Jordan (15\%), Syrian Arab republic (9\% to 22\% between June and September 2020) [23] and Palestine (13\%) [24]. According to our findings, at government level, Beqaa and Akkar have the largest proportion of households with a poor FCS, with $83 \%$ and $73 \%$ of households are calculated to have a poor FCS, respectively. These results came hand by hand with the data published by the world Food Program (WFP) in October 2020, in which Beqaa and Akkar presented the lowest FCS compared to other governorates [25]. In addition, as for livelihoods, our findings found that most Lebanese households reported a decline in income along with an expansion in debt incurrences in the last 24 months; the top reasons for it being the inflations in prices and the unemployment. Moreover, the main reason behind debt incurrence by households was food purchase. In addition, the high rate of unemployment has caused an inflation in salary cuts, which in return reduces the ability to afford adequate and sufficient food. This was obvious in our study, where an increase in income showed an improvement in the FCS. Households who were suffering for monetary instabilities and unemployment, were among the group of poor FCS who were facing failure to meet fundamental needs which this can lead to future physical and mental well-being issues, including malnutrition and depression.

When investigating correlates of coping strategies, our findings showed that households CSI was linked with socioeconomical characteristics including monthly income, monetary debts, and number of family members. According to many studies, similar coping strategies were previously observed among Syrian, Iraqi and Palestinian refugees in Lebanon [26-28], such consuming cheaper food items and borrowing money to purchase food. Such strategies among households with children can have serious impact on the overall health status of children in the short and long term, and it should warrant further attention [29].

According to the area affected by the Beirut port explosions, three out of four households were severely food-insecure as per AFFSS and one out two households were shown to be severely food-insecure, using FIES. Many factors influenced the food security status of households affected by the Beirut explosions including the number of family members, the number of children in each household, low educational attainment, and unemployment. Recent studies support our finding, including 18 countries in the Eastern Mediterranean region (including Lebanon, Palestine, Egypt, Jordan) highlight that the five common correlates of food insecurity across these countries were low levels of education, low household income and unemployment [30,31]. Between 2014 and 2018, the percentage of Lebanese household food insecurity per year ranged between $24 \%$ and $34 \%$, respectively. However, today, according to our findings, the percentage of food-insecure households doubled, mainly in those affected by the Beirut explosions.

All the above findings indicate an alarming situation that is due to the financial and economic crisis that in turn led to a macro-financial failure that included defacement of the banking sector which led to loss of peoples' deposits. In addition, the exchange rate had collapsed resulting in a triple-digit inflation rates along with a severe contraction in the banking sector due to the impacts from the COVID-19 pandemic, including necessary lockdowns that further exacerbated the whole situation [32]. In addition, and since 2011, the overabundance from the Syrian Arab republic resulted in providing the larging refugee population per capita in the world. Moreover, the blast limited the trade of food products, destroyed the plant and animal quarantines offices in Beirut port and destroyed the equipment and laboratories that were in charge for measuring the quality of imported wheat. To add, the small-scale fishing industry was devastated due to the massive death in fishes available close to the epicenter of the blast. As known, new imports must be funded with US Dollars obtained after November 2019, and require advanced payment to foreign suppliers. The restriction on the foreign currency transactions, placed since October 2019, limited the sectors of agribusinesses and the importation of food markets, meats, fish, and chicken resulting in potential shortages in imported food products and animal feeds. All these factors together led to an increase in the cost of the food component of the SMEB 
that reached an aggregate expansion of 109\% between September 2019 and May 2020 [32]. Additionally, a decrease by $14.4 \%$ of food imports was observed between October 2019 and March 2020 compared to October 2018 and March 2019, which caused an overpressure on the prices due to reduce in food availability [32].

\section{Limitations}

The current study has several strengths. It is the first to explore the prevalence and correlates of household food insecurity among Lebanese households since the ordeals of COVID-19, economic crisis, and the Beirut port explosions. The demographic and socioeconomic characteristics of the study sample were found to be comparable to national figures most recently available in Lebanon [25,33]. Other strengths of the study include the use of a culturally sensitive questionnaire and a locally validated household food security access scale. Innovatively and unlike any other information gathering exercise ever conducted before in Lebanon, this assessment fully uses a mobile phone application called NAS which means that no paper forms are used, anyone with a smart-phone can participate, and results are automatically analyzed. For no charge, users had a chance to answer many multiple-choice and open questions regarding their food security status. However, results from the present study need to be interpreted in the light of several limitations. The NAS mobile technology considers people who are literate Internet users, with connectivity to the Internet, hence, the sample was not necessarily representative of all populations but provided trends to help decision-making at administrative level for the Lebanese. Another limitation is the inability to collect data face to face but through technology-based mobile application where there was a gap in collecting anthropometric data. The cross-sectional design of the study allowed us only to examine associations rather than explore potential causal pathways between food insecurity and many other factors. Food insecurity was also measured at the household level, and it may not reflect the severity of food insecurity that is witnessed specifically at the individual level.

\section{Conclusions}

In conclusion, food insecurity is a food system disruptor with serious repercussions for the health and future sustainability of Lebanese households. Three potential areas of consequences of food insecurity at the household level were apparent in these current surveys, namely physical, psychological, and socio-familial. This national assessment of food security in Lebanon was conducted to provide humanitarian and development actors, the government of Lebanon and other non-governmental partners with baseline information to facilitate the development of a comprehensive evidence-based strategy for food security interventions targeting Lebanese communities. Given the multiple dimensions of food security, it is time to track all food security indicators including food availability, access, consumption, and use, and promote sustainable food systems. Key issues include how the intervention in the field of food security can help work towards more resilient households, communities, and food systems, how they can contribute to stability, sustainability, bridging humanitarian and development programming in protracted crisis areas. Achieving food security for all and realizing the right to food is the key aspect of any further assessment and/or intervention.

Author Contributions: Conceptualization, M.H.; Data curation, M.H., S.E.G., R.M. (Reem Mhanna), F.S.-A. and P.S.; Formal analysis, M.H., R.M. (Rania Mansour), R.M. (Reem Mhanna) and F.S.-A.; Investigation, M.H. and A.A.-J.; Methodology, M.H. and Y.A.-A.; Project administration, A.A.-J.; Software, Y.A.-A. and H.J.; Supervision, M.H. and A.A.-J.; Validation, A.A.-J.; Writing—original draft, M.H.; Writing-review \& editing, Y.A.-A., H.J., S.E.G., R.M. (Rania Mansour), R.M. (Reem Mhanna), F.S.-A., P.S. and A.A.-J. All authors have read and agreed to the published version of the manuscript.

Funding: This research received no external funding. 
Institutional Review Board Statement: The study was conducted according to the guidelines of the Declaration of Helsinki and approved by the Institutional Review Board (or Ethics Committee) of the Lebanese university (\#CUER 22-2020).

Informed Consent Statement: Informed consent was obtained from all subjects involved in the study.

Data Availability Statement: This study did not report any data yet.

Acknowledgments: The authors would like to acknowledge all the students from the Faculty of Public Health and The Faculty of Pharmacy who contributed to data collection. Moreover, the authors are grateful to the non-governmental organizations "We Do Association" for their assistance in data collection as well.

Conflicts of Interest: The authors declare no conflict of interest.

Disclaimer: The authors alone are responsible for the views expressed in this article and they do not necessarily represent the views, decisions, or policies of the World Health Organization or the other institutions with which the authors are affiliated.

\section{Appendix A}

Table A1. Socio-demographic and socio-economic characteristics of the survey respondents by their place of living.

\begin{tabular}{|c|c|c|c|c|c|c|c|c|c|c|c|c|c|c|c|c|c|c|}
\hline & \multirow{5}{*}{ Age not reported } & \multicolumn{16}{|c|}{ Place of Living } & \\
\hline & & \multirow{2}{*}{\multicolumn{2}{|c|}{$\begin{array}{l}\text { Beirut } \\
\mathrm{N}(\%)\end{array}$}} & \multirow{2}{*}{\multicolumn{2}{|c|}{$\begin{array}{c}\text { Mount Lebanon } \\
\mathrm{N}(\%)\end{array}$}} & \multirow{2}{*}{\multicolumn{2}{|c|}{$\begin{array}{l}\text { North } \\
\mathrm{N}(\%)\end{array}$}} & \multirow{2}{*}{\multicolumn{2}{|c|}{$\begin{array}{l}\text { South } \\
\mathrm{N}(\%)\end{array}$}} & \multirow{2}{*}{\multicolumn{2}{|c|}{$\begin{array}{c}\text { Beqaa } \\
\mathrm{N}(\%)\end{array}$}} & \multirow{2}{*}{\multicolumn{2}{|c|}{$\begin{array}{c}\text { Nabatieh } \\
\mathrm{N}(\%)\end{array}$}} & \multirow{2}{*}{\multicolumn{2}{|c|}{$\begin{array}{c}\begin{array}{c}\text { Baalbek-El } \\
\text { Hermel }\end{array} \\
\mathrm{N}(\%) \\
\end{array}$}} & \multicolumn{2}{|c|}{ Akkar } & \\
\hline & & & & & & & & & & & & & & & & & & Sig. \\
\hline \multirow{6}{*}{ Age categories } & & 20 & 4.9 & 11 & 10.1 & 2 & 2.4 & 45 & 14.6 & 9 & 21.1 & 1 & 5.8 & 9 & 23.1 & 35 & 24.1 & \\
\hline & & 58 & 14.4 & 11 & 9.7 & 18 & 26.3 & 37 & 11.8 & 2 & 4.7 & 0 & 3.9 & 1 & 2.4 & 2 & 1.1 & \\
\hline & $20-24$ & 74 & 18.1 & 32 & 29.0 & 5 & 7.5 & 45 & 14.4 & 4 & 9.1 & 5 & 45.9 & 9 & 24.6 & 21 & 14.6 & 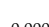 \\
\hline & $25-34$ & 102 & 25.2 & 10 & 8.6 & 25 & 37.2 & 70 & 22.6 & 10 & 24.8 & 4 & 33.8 & 2 & 4.4 & 53 & 36.3 & 0.000 \\
\hline & $35-54$ & 125 & 31.0 & 38 & 34.5 & 17 & 25.5 & 105 & 33.7 & 17 & 40.3 & 1 & 8.2 & 17 & 45.5 & 26 & 17.9 & \\
\hline & $55+$ & 26 & 6.4 & 9 & 7.9 & 1 & 1.0 & 9 & 2.9 & 0 & 0.0 & 0 & 2.4 & 0 & 0.0 & 9 & 6.0 & \\
\hline \multirow[b]{2}{*}{ Gender } & Female & 234 & 57.6 & 70 & 63.7 & 47 & 68.6 & 144 & 46.3 & 40 & 96.5 & 10 & 83.0 & 28 & 74.0 & 20 & 14.0 & \\
\hline & Male & 172 & 42.4 & 40 & 36.3 & 21 & 31.4 & 167 & 53.7 & 1 & 3.5 & 2 & 17.0 & 10 & 26.0 & 126 & 86.0 & 0.000 \\
\hline \multirow{4}{*}{ Marital Status } & Single & 194 & 47.9 & 50 & 45.4 & 38 & 54.9 & 141 & 45.2 & 23 & 55.9 & 8 & 70.6 & 11 & 30.2 & 68 & 46.6 & \\
\hline & Married & 211 & 52.0 & 51 & 46.0 & 31 & 44.8 & 154 & 49.4 & 18 & 44.1 & 3 & 27.5 & 26 & 69.2 & 70 & 47.7 & \\
\hline & Widow & 0 & 0.0 & 0 & 0.0 & 0 & 0.0 & 0 & 0.0 & 0 & 0.0 & 0 & 0.0 & 0 & 0.0 & 0 & 0.2 & 0.000 \\
\hline & Divorced & 0 & 0.1 & 9 & 8.5 & 0 & 0.3 & 17 & 5.4 & 0 & 0.0 & 0 & 1.9 & 0 & 0.6 & 8 & 5.5 & \\
\hline \multirow{4}{*}{$\begin{array}{c}\text { Number of family } \\
\text { members }\end{array}$} & 1-3 members & 96 & 23.8 & 42 & 38.5 & 31 & 45.5 & 33 & 10.8 & 11 & 25.4 & 5 & 39.6 & 9 & 23.7 & 35 & 24.0 & \\
\hline & 4-6 members & 299 & 73.9 & 65 & 59.4 & 21 & 30.1 & 238 & 76.5 & 31 & 73.5 & 6 & 46.9 & 28 & 73.9 & 66 & 44.9 & \\
\hline & 7-9 members & 9 & 2.3 & 2 & 1.9 & 17 & 24.3 & 39 & 12.6 & 0 & 1.1 & 2 & 13.5 & 1 & 1.8 & 28 & 19.0 & 0.000 \\
\hline & More than 9 members & 0 & 0.0 & 0 & 0.2 & 0 & 0.0 & 0 & 0.1 & 0 & 0.0 & 0 & 0.0 & 0 & 0.6 & 18 & 12.1 & \\
\hline \multirow{3}{*}{ Number of children } & 0 children & 138 & 34.1 & 22 & 20.0 & 18 & 26.4 & 102 & 32.9 & 28 & 66.6 & 6 & 48.3 & 2 & 5.8 & 37 & 25.1 & \\
\hline & Fewer than 3 children & 159 & 39.2 & 60 & 54.5 & 40 & 58.9 & 167 & 53.8 & 12 & 28.1 & 4 & 37.7 & 26 & 68.9 & 55 & 37.4 & 0.000 \\
\hline & More than 3 children & 108 & 26.7 & 28 & 25.5 & 10 & 14.6 & 41 & 13.3 & 2 & 5.2 & 2 & 14.0 & 10 & 25.3 & 55 & 37.5 & 0.000 \\
\hline \multirow{4}{*}{ Education } & Illiterate & 8 & 2.0 & 0 & 0.0 & 0 & 0.0 & 9 & 2.8 & 0 & 0.0 & 0 & 0.0 & 0 & 0.0 & 9 & 6.0 & \\
\hline & Primary & 9 & 2.1 & 0 & 0.0 & 17 & 24.5 & 25 & 8.2 & 0 & 0.0 & 0 & 0.0 & 0 & 0.0 & 8 & 5.5 & \\
\hline & intermediate & 300 & 74.2 & 75 & 68.1 & 33 & 48.1 & 235 & 75.7 & 32 & 77.2 & 0 & 0.0 & 33 & 86.6 & 121 & 83.0 & 0.000 \\
\hline & University & 88 & 21.7 & 35 & 31.9 & 19 & 27.4 & 41 & 13.3 & 10 & 22.8 & 12 & 100.0 & 5 & 13.4 & 8 & 5.6 & \\
\hline \multirow{4}{*}{ Occupation } & Working & 173 & 42.8 & 40 & 36.3 & 34 & 49.1 & 134 & 43.1 & 1 & 3.4 & 6 & 48.3 & 10 & 26.7 & 36 & 24.7 & \\
\hline & & 30 & 7.4 & 19 & 17.5 & 0 & 0.3 & 29 & 9.3 & 0 & 0.6 & 0 & 3.9 & 8 & 21.2 & 35 & 24.0 & \\
\hline & Not working & 105 & 26.0 & 27 & 24.9 & 10 & 14.5 & 86 & 27.6 & 33 & 78.4 & 1 & 12.1 & 9 & 23.7 & 60 & 41.0 & 0.000 \\
\hline & Student & 97 & 23.9 & 23 & 21.3 & 25 & 36.1 & 62 & 20.0 & 7 & 17.7 & 4 & 35.7 & 11 & 28.4 & 15 & 10.3 & \\
\hline \multirow{2}{*}{ Health Occupation } & & 27 & 6.7 & 11 & 9.6 & 4 & 5.5 & 7 & 2.2 & 3 & 6.1 & 4 & 31.9 & 9 & 23.1 & 0 & 0.2 & \\
\hline & No & 378 & 93.3 & 100 & 90.4 & $\begin{array}{l}4 \\
65 \\
\end{array}$ & 94.5 & 304 & 97.8 & 39 & $\begin{array}{l}0.1 \\
93.9\end{array}$ & $\begin{array}{l}7 \\
8\end{array}$ & 68.1 & 29 & 76.9 & 146 & 9.2 & 0.000 \\
\hline \multirow{4}{*}{ Smoking } & Yes & 74 & 18.3 & 36 & 32.3 & 18 & 26.0 & 105 & 33.8 & 9 & 21.3 & 1 & 4.4 & 9 & 23.7 & 80 & 54.6 & \multirow{4}{*}{0.000} \\
\hline & No & 298 & 73.6 & 72 & 65.2 & 48 & 70.5 & 187 & 60.2 & 33 & 78.7 & 10 & 86.9 & 28 & 74.9 & 58 & 39.9 & \\
\hline & Sometimes & 30 & 7.4 & 2 & 1.8 & 2 & 3.0 & 9 & 3.0 & 0 & 0.0 & 1 & 6.3 & 0 & 0.6 & 8 & 5.5 & \\
\hline & Old smoker & 3 & 0.7 & 1 & 0.6 & 0 & 0.4 & 10 & 3.1 & 0 & 0.0 & 0 & 2.4 & 0 & 0.8 & 0 & 0.0 & \\
\hline
\end{tabular}

Table A1. Cont.

\begin{tabular}{|c|c|c|c|c|c|c|c|c|c|c|c|c|c|c|c|c|c|c|}
\hline & & \multicolumn{16}{|c|}{ Place of Living } & \\
\hline & & \multicolumn{2}{|c|}{ Beirut } & \multicolumn{2}{|c|}{ Mount Lebanon } & \multicolumn{2}{|c|}{ North } & \multicolumn{2}{|c|}{ South } & \multicolumn{2}{|c|}{ Beqaa } & \multicolumn{2}{|c|}{ Nabatieh } & \multicolumn{2}{|c|}{$\begin{array}{c}\text { Baalbek-El } \\
\text { Hermel }\end{array}$} & \multicolumn{2}{|c|}{ Akkar } & \\
\hline & & \multicolumn{2}{|c|}{$\mathrm{N}(\%)$} & \multicolumn{2}{|c|}{$\mathrm{N}(\%)$} & \multicolumn{2}{|c|}{$\mathrm{N}(\%)$} & \multicolumn{2}{|c|}{$\mathrm{N}(\%)$} & \multicolumn{2}{|c|}{$\mathrm{N}(\%)$} & \multicolumn{2}{|c|}{$\mathrm{N}(\%)$} & \multicolumn{2}{|c|}{$\mathrm{N}(\%)$} & \multicolumn{2}{|c|}{$\mathrm{N}(\%)$} & Sig. \\
\hline \multirow{7}{*}{ Monthly income } & No income & 31 & 7.6 & 1 & 1.0 & 20 & 29.0 & 81 & 26.1 & 16 & 39.2 & 1 & 4.4 & 9 & 22.6 & 69 & 47.3 & \multirow{7}{*}{0.000} \\
\hline & less than 1,500,000 LBP & 146 & 36.0 & 52 & 46.8 & 30 & 43.2 & 138 & 44.5 & 18 & 44.0 & 3 & 28.0 & 2 & 6.2 & 37 & 25.6 & \\
\hline & $1,500,000-3,000,000$ LBP & 111 & 27.5 & 22 & 19.8 & 14 & 19.8 & 45 & 14.4 & 4 & 9.5 & 4 & 31.4 & 19 & 49.3 & 20 & 13.8 & \\
\hline & More than $3,000,000 \mathrm{LBP}$ & 19 & 4.8 & 13 & 11.5 & 2 & 3.4 & 4 & 1.2 & 2 & 3.9 & 3 & 26.1 & 0 & 0.0 & 1 & 1.0 & \\
\hline & Less than USD 1000 & 46 & 11.4 & 2 & 1.7 & 1 & 1.1 & 30 & 9.6 & 1 & 1.7 & 0 & 3.9 & 8 & 21.2 & 9 & 6.0 & \\
\hline & USD $1000-2000$ & 40 & 9.8 & 20 & 18.2 & 1 & 0.8 & 4 & 1.1 & 1 & 1.2 & 1 & 6.3 & 0 & 0.6 & 0 & 0.0 & \\
\hline & More than USD 2000 & 12 & 2.9 & 1 & 0.9 & 2 & 2.8 & 10 & 3.1 & 0 & 0.6 & 0 & 0.0 & 0 & 0.0 & 9 & 6.3 & \\
\hline
\end{tabular}




\section{Appendix B}

Table A2. Depts incurrence and assistance related to the survey's respondents according to gender and their place of living.

\begin{tabular}{|c|c|c|c|c|c|c|c|c|c|c|c|c|c|c|c|c|c|c|}
\hline \multirow[b]{4}{*}{$\begin{array}{l}\text { Incurred any debts in the } \\
\text { last } 24 \text { months }\end{array}$} & \multirow[b]{4}{*}{$\begin{array}{l}\text { Yes } \\
\text { No }\end{array}$} & \multicolumn{16}{|c|}{ Place of Living } & \\
\hline & & \multirow{2}{*}{\multicolumn{2}{|c|}{$\begin{array}{l}\text { Beirut } \\
\mathrm{N}(\%)\end{array}$}} & \multirow{2}{*}{\multicolumn{2}{|c|}{$\begin{array}{c}\text { Mount Lebanon } \\
\mathrm{N}(\%)\end{array}$}} & \multirow{2}{*}{\multicolumn{2}{|c|}{$\begin{array}{l}\text { North } \\
\mathrm{N}(\%)\end{array}$}} & \multirow{2}{*}{\multicolumn{2}{|c|}{$\begin{array}{l}\text { South } \\
\mathrm{N}(\%)\end{array}$}} & \multirow{2}{*}{\multicolumn{2}{|c|}{$\begin{array}{l}\text { Beqaa } \\
\mathrm{N}(\%)\end{array}$}} & \multirow{2}{*}{\multicolumn{2}{|c|}{$\begin{array}{c}\text { Nabatieh } \\
\mathbf{N}(\%)\end{array}$}} & \multirow{2}{*}{\multicolumn{2}{|c|}{$\begin{array}{c}\begin{array}{c}\text { Baalbek-El } \\
\text { Hermel }\end{array} \\
\mathrm{N}(\%)\end{array}$}} & \multicolumn{3}{|c|}{ Akkar } \\
\hline & & & & & & & & & & & & & & & & & & Sig. \\
\hline & & $\begin{array}{l}189 \\
216\end{array}$ & $\begin{array}{l}46.6 \\
53.4\end{array}$ & $\begin{array}{l}74 \\
36\end{array}$ & $\begin{array}{l}67.4 \\
32.6\end{array}$ & $\begin{array}{l}30 \\
38\end{array}$ & $\begin{array}{l}44.0 \\
56.0\end{array}$ & $\begin{array}{l}135 \\
176\end{array}$ & $\begin{array}{l}43.5 \\
56.5\end{array}$ & $\begin{array}{c}36 \\
6\end{array}$ & $\begin{array}{l}85.8 \\
14.2\end{array}$ & $\begin{array}{l}5 \\
7\end{array}$ & $\begin{array}{l}41.5 \\
58.5\end{array}$ & $\begin{array}{l}27 \\
10\end{array}$ & $\begin{array}{l}72.4 \\
27.6\end{array}$ & $\begin{array}{l}116 \\
30\end{array}$ & $\begin{array}{l}79.3 \\
20.7\end{array}$ & 0.000 \\
\hline \multirow{4}{*}{$\begin{array}{l}\text { Amount of dept the } \\
\text { participant currently has }\end{array}$} & $\begin{array}{c}\text { more than or equal USD } \\
10,000\end{array}$ & 6 & 1.5 & 11 & 10.3 & 8 & 12.1 & 1 & 0.3 & 0 & 0.7 & 0 & 3.9 & 0 & 0.0 & 18 & 12.5 & \multirow{4}{*}{0.000} \\
\hline & $\begin{array}{c}\text { less than USD 10,000 } \\
\text { no debt }\end{array}$ & $\begin{array}{c}76 \\
237\end{array}$ & $\begin{array}{l}18.6 \\
58.4\end{array}$ & $\begin{array}{l}13 \\
64\end{array}$ & $\begin{array}{l}12.0 \\
58.2\end{array}$ & $\begin{array}{c}1 \\
48\end{array}$ & $\begin{array}{c}1.4 \\
70.4\end{array}$ & $\begin{array}{c}46 \\
219\end{array}$ & $\begin{array}{l}15.0 \\
70.6\end{array}$ & $\begin{array}{c}17 \\
6\end{array}$ & $\begin{array}{l}40.8 \\
15.3\end{array}$ & $\begin{array}{l}2 \\
8\end{array}$ & $\begin{array}{l}15.4 \\
65.3\end{array}$ & $\begin{array}{c}1 \\
27\end{array}$ & $\begin{array}{l}3.2 \\
70.1\end{array}$ & $\begin{array}{c}0 \\
56\end{array}$ & $\begin{array}{c}0.2 \\
38.5\end{array}$ & \\
\hline & \multirow{2}{*}{$\begin{array}{l}\text { no debt } \\
\text { less than } 15 \text { million LBP } \\
\text { more than or equal } 15 \\
\text { million LBP }\end{array}$} & 73 & 18.0 & 11 & 9.6 & 10 & 14.4 & 34 & 11.0 & 9 & 22.1 & 1 & 9.6 & 9 & 24.3 & 62 & 42.6 & \\
\hline & & 14 & 3.5 & 11 & 9.9 & 1 & 1.7 & 10 & 3.2 & 9 & 21.1 & 1 & 5.8 & 1 & 2.4 & 9 & 6.3 & \\
\hline \multirow{5}{*}{$\begin{array}{l}\text { When the participant took } \\
\text { the dept }\end{array}$} & \multirow{5}{*}{$\begin{array}{l}\text { Missing } \\
\text { one month ago } \\
\text { during the last } 6 \text { months } \\
\text { during the last } 12 \text { months } \\
\text { during the last } 24 \text { months } \\
\text { or more }\end{array}$} & 216 & 53.4 & 36 & 32.6 & 38 & 56.0 & 176 & 56.5 & 6 & 14.2 & 7 & 58.5 & 10 & 27.6 & 30 & 20.7 & \multirow{5}{*}{0.000} \\
\hline & & 10 & 2.5 & 1 & 0.8 & 0 & 0.0 & 1 & 0.2 & 0 & 0.0 & 0 & 1.9 & 0 & 0.6 & 9 & 6.1 & \\
\hline & & 37 & 9.2 & 1 & 1.3 & 9 & 13.5 & 42 & 13.4 & 18 & 43.2 & 2 & 17.9 & 17 & 44.3 & 27 & 18.4 & \\
\hline & & 51 & 12.6 & 20 & 17.8 & 9 & 13.8 & 28 & 9.0 & 0 & 0.6 & 0 & 3.9 & 9 & 23.1 & 35 & 24.3 & \\
\hline & & 90 & 22.3 & 52 & 47.4 & 11 & 16.7 & 65 & 20.8 & 18 & 42.1 & 2 & 17.9 & 2 & 4.4 & 45 & 30.5 & \\
\hline \multirow{3}{*}{ Way of dept payment } & Missing & 216 & 53.4 & 36 & 32.6 & 38 & 56.0 & 176 & 56.5 & 6 & 14.2 & 7 & 58.5 & 10 & 27.6 & 30 & 20.7 & \multirow{3}{*}{0.000} \\
\hline & total payments & 1 & 0.3 & 0 & 0.2 & 1 & 1.1 & 9 & 3.0 & 0 & 0.0 & 0 & 0.0 & 0 & 0.0 & 9 & 6.3 & \\
\hline & monthly payments & & 46.3 & 74 & 67.1 & 29 & 42.9 & 126 & 40.4 & 36 & 85.8 & 5 & 41.5 & 27 & 72.4 & 107 & 73.0 & \\
\hline \multirow{2}{*}{$\begin{array}{l}\text { Receiving assistance in the } \\
\text { last } 12 \text { months }\end{array}$} & Yes & 80 & 19.7 & 24 & 21.8 & 10 & 14.9 & 92 & 29.5 & 18 & 42.1 & 1 & 9.6 & 10 & 25.0 & 10 & 6.6 & \multirow{2}{*}{0.000} \\
\hline & No & 325 & 80.3 & 86 & 78.2 & 58 & 85.1 & 219 & 70.5 & 24 & 57.9 & 11 & 90.4 & 28 & 75.0 & 136 & 93.4 & \\
\hline \multirow{9}{*}{$\begin{array}{l}\text { Type of assistance the } \\
\text { participant gets }\end{array}$} & Missing & 325 & 80.3 & 86 & 78.2 & 58 & 85.1 & 219 & 70.5 & 24 & 57.9 & 11 & 90.4 & 28 & 75.0 & 136 & 93.4 & \\
\hline & Food & 60 & 14.7 & 23 & 20.5 & 1 & 1.9 & 47 & 15.0 & 17 & 39.9 & 1 & 5.8 & 9 & 24.4 & 9 & 6.3 & \\
\hline & Cash & 12 & 2.9 & 1 & 0.9 & 9 & 12.6 & 35 & 11.4 & 1 & 2.2 & 0 & 1.9 & 0 & 0.6 & 0 & 0.0 & \\
\hline & Non-food items & 0 & 0.0 & 0 & 0.0 & 0 & 0.0 & 0 & 0.1 & 0 & 0.0 & 0 & 1.9 & 0 & 0.0 & 0 & 0.0 & \\
\hline & Education & 8 & 2.0 & 1 & 0.5 & 0 & 0.3 & 9 & 2.8 & 0 & 0.0 & 0 & 0.0 & 0 & 0.0 & 0 & 0.0 & 0.000 \\
\hline & Health & 1 & 0.1 & 0 & 0.0 & 0 & 0.0 & 0 & 0.1 & 0 & 0.0 & 0 & 0.0 & 0 & 0.0 & 0 & 0.2 & \\
\hline & Protection & 0 & 0.0 & 0 & 0.0 & 0 & 0.0 & 0 & 0.0 & 0 & 0.0 & 0 & 0.0 & 0 & 0.0 & 0 & 0.0 & \\
\hline & Shelter & 0 & 0.0 & 0 & 0.0 & 0 & 0.0 & 0 & 0.1 & 0 & 0.0 & 0 & 0.0 & 0 & 0.0 & 0 & 0.0 & \\
\hline & WASH & 0 & 0.0 & 0 & 0.0 & 0 & 0.0 & 0 & 0.0 & 0 & 0.0 & 0 & 0.0 & 0 & 0.0 & 0 & 0.2 & \\
\hline & Missing & 326 & 80.3 & 86 & 78.2 & 58 & 85.1 & 219 & 70.5 & 24 & 57.9 & 11 & 90.4 & 28 & 75.0 & 136 & 93.4 & \\
\hline & Government & 11 & 2.7 & 1 & 1.3 & 8 & 12.2 & 27 & 8.7 & 0 & 1.1 & 0 & 1.9 & 0 & 0.6 & 0 & 0.2 & \\
\hline & NGO & 20 & 4.9 & 0 & 0.4 & 1 & 0.8 & 18 & 5.9 & 0 & 0.7 & 0 & 0.0 & 0 & 0.6 & 0 & 0.0 & \\
\hline & Charity & 28 & 7.0 & 12 & 10.6 & 0 & 0.4 & 9 & 2.9 & 16 & 38.6 & 0 & 1.9 & 0 & 1.2 & 0 & 0.0 & \\
\hline Source of assistance & UN agency & 8 & 2.0 & 0 & 0.0 & 0 & 0.3 & 17 & 5.5 & 0 & 0.0 & 0 & 1.9 & 0 & 0.0 & 9 & 6.1 & 0.000 \\
\hline & religious organization & 1 & 0.2 & 10 & 8.6 & 0 & 0.4 & 1 & 0.2 & 0 & 0.0 & 0 & 3.9 & 0 & 0.6 & 0 & $\begin{array}{l}0.1 \\
0.0\end{array}$ & \\
\hline & local people & 10 & 2.5 & 1 & 0.6 & 0 & 0.3 & 11 & 3.4 & 0 & 1.1 & 0 & 0.0 & 8 & 22.0 & 0 & 0.2 & \\
\hline & family aboard & 1 & 0.3 & 0 & 0.3 & 0 & 0.4 & 9 & 2.9 & 0 & 0.6 & 0 & 0.0 & 0 & 0.0 & 0 & 0.2 & \\
\hline
\end{tabular}

\section{Appendix C}

Table A3. Food groups consumption per week in the previous 7 days for respondents according to their place of living.

\begin{tabular}{|c|c|c|c|c|c|c|c|c|c|c|c|c|c|c|c|c|c|c|}
\hline \multirow{5}{*}{$\begin{array}{l}\text { Number of meals per day one } \\
\text { day before }\end{array}$} & \multirow{5}{*}{$\begin{array}{l}2 \text { meals and less } \\
3 \text { meals and more }\end{array}$} & \multicolumn{16}{|c|}{ Place of Living } & \\
\hline & & \multirow{2}{*}{\multicolumn{2}{|c|}{$\begin{array}{l}\text { Beirut } \\
\mathrm{N}(\%)\end{array}$}} & \multirow{2}{*}{\multicolumn{2}{|c|}{$\begin{array}{c}\text { Mount Lebanon } \\
\mathrm{N}(\%)\end{array}$}} & \multicolumn{2}{|c|}{ North } & \multicolumn{2}{|c|}{ South } & \multicolumn{2}{|c|}{ Beqaa } & \multicolumn{2}{|c|}{ Nabatieh } & \multicolumn{2}{|c|}{$\begin{array}{l}\text { Baalbek-El } \\
\text { Hermel }\end{array}$} & \multicolumn{2}{|c|}{ Akkar } & \multirow[b]{2}{*}{ Sig. } \\
\hline & & & & & & & & & & & & & & & & & & \\
\hline & & 247 & 61.1 & 50 & 45.5 & 22 & 31.5 & 195 & 62.7 & 20 & 48.8 & 7 & 59.9 & 19 & 49.9 & 72 & 49.3 & \\
\hline & & 158 & 38.9 & 60 & 54.5 & 47 & 68.5 & 116 & 37.3 & 21 & 51.2 & 5 & 40.1 & 19 & 50.1 & 74 & 50.7 & 0.000 \\
\hline \multirow{3}{*}{ being as usual, less, or more } & as usual & 305 & 75.2 & 96 & 87.0 & 67 & 97.2 & 218 & 70.2 & 24 & 57.2 & 9 & 75.3 & 28 & 75.0 & 66 & 45.2 & \multirow{3}{*}{0.000} \\
\hline & less than usual & 11 & 2.8 & 1 & 0.9 & 0 & 0.4 & 10 & 3.2 & 0 & 0.0 & 1 & 8.2 & 0 & 0.0 & 0 & 0.2 & \\
\hline & more than usual & 89 & 22.0 & 13 & 12.1 & 2 & 2.4 & 83 & 26.6 & 18 & 42.8 & 2 & 16.4 & 10 & 25.0 & 80 & 54.6 & \\
\hline \multirow{2}{*}{ Cereal consumption per week } & fewer than 3 days & 282 & 69.6 & 68 & 61.6 & 60 & 88.1 & 176 & 56.5 & 37 & 87.6 & 4 & 34.3 & 36 & 95.6 & 126 & 86.0 & \multirow[b]{2}{*}{0.000} \\
\hline & 4 days and more & 123 & 30.4 & 42 & 38.4 & 8 & 11.9 & 135 & 43.5 & 5 & 12.4 & 8 & 65.7 & 2 & 4.4 & 20 & 14.0 & \\
\hline \multirow{2}{*}{$\begin{array}{l}\text { White tubers consumption } \\
\text { per week }\end{array}$} & fewer than 3 days & 296 & 73.1 & 84 & 76.5 & 48 & 70.5 & 183 & 58.8 & 31 & 75.2 & 8 & 64.3 & 37 & 98.2 & 144 & 98.6 & \multirow[b]{2}{*}{0.000} \\
\hline & 4 days and more & 109 & 26.9 & 26 & 23.5 & 20 & 29.5 & 128 & 41.2 & 10 & 24.8 & 4 & 35.7 & 1 & 1.8 & 2 & 1.4 & \\
\hline \multirow{2}{*}{ Vegetable consumption per week } & fewer than 3 days & 269 & 66.3 & 68 & 61.8 & 62 & 90.8 & 211 & 67.9 & 29 & 68.4 & 6 & 54.1 & 37 & 96.2 & 125 & 85.5 & \multirow[b]{2}{*}{0.000} \\
\hline & 4 days and more & 136 & 33.7 & 42 & 38.2 & 6 & 9.2 & 100 & 32.1 & 13 & 31.6 & 5 & 45.9 & 1 & 3.8 & 21 & 14.5 & \\
\hline \multirow{2}{*}{ Fruit consumption per week } & fewer than 3 days & 273 & 67.3 & 84 & 76.0 & 44 & 64.9 & 219 & 70.3 & 28 & 66.6 & 5 & 42.5 & 28 & 74.4 & 125 & 85.5 & \multirow{2}{*}{0.000} \\
\hline & 4 days and more & 133 & 32.7 & 26 & 24.0 & 24 & 35.1 & 92 & 29.7 & 14 & 33.4 & 7 & 57.5 & 10 & 25.6 & 21 & 14.5 & \\
\hline \multirow{2}{*}{ Eggs consumption per week } & fewer than 3 days & 312 & 77.1 & 98 & 88.8 & 49 & 71.8 & 263 & 84.5 & 40 & 95.0 & 8 & 66.2 & 37 & 98.0 & 135 & 92.7 & \multirow{2}{*}{0.000} \\
\hline & 4 days and more & 93 & 22.9 & 12 & 11.2 & 19 & 28.2 & 48 & 15.5 & 2 & 5.0 & 4 & 33.8 & 1 & 2.0 & 11 & 7.3 & \\
\hline Pulse and nuts consumption & fewer than 3 days & 359 & 88.6 & 106 & 96.2 & 65 & 94.7 & 263 & 84.6 & 33 & 77.9 & 9 & 73.4 & 29 & 76.8 & 136 & 93.2 & \\
\hline per week & 4 days and more & 46 & 11.4 & 4 & 3.8 & 4 & 5.3 & 48 & 15.4 & 9 & 22.1 & 3 & 26.6 & 9 & 23.2 & 10 & 6.8 & 0.000 \\
\hline Dairy products consumption & fewer than 3 days & 316 & 78.0 & 82 & 74.1 & 45 & 65.8 & 220 & 70.9 & 37 & 89.8 & 7 & 61.8 & 29 & 76.9 & 135 & 92.7 & \\
\hline per week & 4 days and more & 89 & 22.0 & 29 & 25.9 & 23 & 34.2 & 91 & 29.1 & 4 & 10.2 & 5 & 38.2 & 9 & 23.1 & 11 & 7.3 & 0.000 \\
\hline Fat and oils consumption & fewer than 3 days & 307 & 75.9 & 80 & 72.8 & 46 & 67.5 & 186 & 59.7 & 38 & 90.9 & 7 & 54.6 & 29 & 75.6 & 127 & 86.7 & \\
\hline per week & 4 days and more & 98 & 24.1 & 30 & 27.2 & 22 & 32.5 & 125 & 40.3 & 4 & 9.1 & 5 & 45.4 & 9 & 24.4 & 19 & 13.3 & 0.000 \\
\hline Sweets consumption per week & fewer than 3 days & 320 & 78.9 & 97 & 88.2 & 46 & 66.8 & 210 & 67.5 & 37 & 89.7 & 7 & 56.5 & 28 & 74.4 & 126 & 86.3 & \\
\hline Sweets consumption per week & 4 days and more & 86 & 21.1 & 13 & 11.8 & 23 & 33.2 & 101 & 32.5 & 4 & 10.3 & 5 & 43.5 & 10 & 25.6 & 20 & 13.7 & 0.000 \\
\hline Spices and condiments & fewer than 3 days & 310 & 76.6 & 70 & 63.7 & 45 & 66.4 & 246 & 79.3 & 29 & 68.8 & 7 & 59.9 & 28 & 74.2 & 135 & 92.3 & \\
\hline consumption per week & 4 days and more & 95 & 23.4 & 40 & 36.3 & 23 & 33.6 & 65 & 20.7 & 13 & 31.2 & 5 & 40.1 & 10 & 25.8 & 11 & 7.7 & 0.000 \\
\hline Meat consumption per week & fewer than 3 days & 305 & 75.2 & 93 & 84.0 & 63 & 91.9 & 233 & 75.0 & 39 & 94.2 & 9 & 72.5 & 21 & 54.6 & 145 & 99.4 & 0.000 \\
\hline Meat consumption per week & 4 days and more & 100 & 24.8 & 18 & 16.0 & 6 & 8.1 & 78 & 25.0 & 2 & 5.8 & 3 & 27.5 & 17 & 45.4 & 1 & 0.6 & 0.000 \\
\hline Fish consumption per week & fewer than 3 days & 391 & 96.5 & 101 & 91.5 & 67 & 98.1 & 292 & 94.0 & 41 & 98.3 & 11 & 88.4 & 30 & 78.8 & 137 & 93.7 & 1 \\
\hline & 4 days and more & 14 & 3.5 & 9 & 8.5 & 1 & 1.9 & 19 & 6.0 & 1 & 1.7 & 1 & 11.6 & 8 & 21.2 & 9 & 6.3 & 0.001 \\
\hline
\end{tabular}




\section{Appendix D}

Table A4. Food-based coping strategies in the previous 7 days for respondents according to their place of living.

\begin{tabular}{|c|c|c|c|c|c|c|c|c|c|c|c|c|c|c|c|c|c|c|}
\hline \multirow[b]{4}{*}{ Eating cheaper foods } & \multirow{4}{*}{$\begin{array}{l}\text { fewer than } 3 \text { days } \\
4 \text { days and more }\end{array}$} & \multicolumn{16}{|c|}{ Place of Living } & \\
\hline & & \multirow{2}{*}{\multicolumn{2}{|c|}{$\begin{array}{l}\text { Beirut } \\
\mathrm{N}(\%)\end{array}$}} & \multirow{2}{*}{\multicolumn{2}{|c|}{$\begin{array}{c}\text { Mount Lebanon } \\
\mathrm{N}(\%)\end{array}$}} & \multirow{2}{*}{\multicolumn{2}{|c|}{$\begin{array}{l}\text { North } \\
\mathrm{N}(\%)\end{array}$}} & \multirow{2}{*}{\multicolumn{2}{|c|}{$\begin{array}{l}\text { South } \\
\mathrm{N}(\%)\end{array}$}} & \multirow{2}{*}{\multicolumn{2}{|c|}{$\begin{array}{l}\text { Beqaa } \\
\mathrm{N}(\%)\end{array}$}} & \multirow{2}{*}{\multicolumn{2}{|c|}{$\begin{array}{c}\text { Nabatieh } \\
\mathrm{N}(\%)\end{array}$}} & \multirow{2}{*}{\multicolumn{2}{|c|}{$\begin{array}{c}\begin{array}{c}\text { Baalbek-El } \\
\text { Hermel }\end{array} \\
\mathbf{N}(\%)\end{array}$}} & \multicolumn{3}{|c|}{ Akkar } \\
\hline & & & & & & & & & & & & & & & & & & Sig. \\
\hline & & $\begin{array}{l}157 \\
25\end{array}$ & $\begin{array}{l}86.2 \\
13.8\end{array}$ & $\begin{array}{l}38 \\
12\end{array}$ & 75.4 & 32 & 97.1 & $\begin{array}{l}90 \\
88\end{array}$ & $\begin{array}{l}50.6 \\
49.4\end{array}$ & 27 & 99.1 & 4 & 71.3 & 26 & 98.3 & 106 & 84.9 & 0.000 \\
\hline Borrowing food & $\begin{array}{l}\text { fewer than } 3 \text { days } \\
4 \text { days and more }\end{array}$ & $\begin{array}{l}76 \\
26\end{array}$ & $\begin{array}{l}74.5 \\
25.5\end{array}$ & $\begin{array}{c}20 \\
0\end{array}$ & $\begin{array}{l}98.8 \\
1.2\end{array}$ & $\begin{array}{c}10 \\
0\end{array}$ & $\begin{array}{l}100.0 \\
0.0\end{array}$ & $\begin{array}{l}81 \\
26\end{array}$ & $\begin{array}{l}75.8 \\
24.2\end{array}$ & $\begin{array}{l}0 \\
0\end{array}$ & $\begin{array}{l}100.0 \\
0.0\end{array}$ & $\begin{array}{l}1 \\
0\end{array}$ & $\begin{array}{l}75.0 \\
25.0\end{array}$ & $\begin{array}{l}8 \\
0\end{array}$ & $\begin{array}{l}100.0 \\
0.0\end{array}$ & $\begin{array}{c}54 \\
0\end{array}$ & $\begin{array}{l}100.0 \\
0.0\end{array}$ & 0.000 \\
\hline $\begin{array}{l}\text { Eating less meals to spare } \\
\text { food for children }\end{array}$ & $\begin{array}{l}\text { fewer than } 3 \text { days } \\
4 \text { days and more }\end{array}$ & $\begin{array}{l}92 \\
36\end{array}$ & $\begin{array}{l}71.7 \\
28.3\end{array}$ & $\begin{array}{l}41 \\
10\end{array}$ & $\begin{array}{l}80.6 \\
19.4\end{array}$ & $\begin{array}{c}21 \\
0\end{array}$ & $\begin{array}{c}97.9 \\
2.1\end{array}$ & $\begin{array}{l}83 \\
77\end{array}$ & $\begin{array}{l}51.8 \\
48.2\end{array}$ & $\begin{array}{c}26 \\
1\end{array}$ & $\begin{array}{c}98.0 \\
2.0\end{array}$ & $\begin{array}{l}3 \\
0\end{array}$ & $\begin{array}{c}92.2 \\
7.8\end{array}$ & $\begin{array}{c}18 \\
9\end{array}$ & $\begin{array}{l}67.5 \\
32.5\end{array}$ & $\begin{array}{c}124 \\
9\end{array}$ & $\begin{array}{c}93.2 \\
6.8\end{array}$ & 0.000 \\
\hline Eating small amounts & $\begin{array}{l}\text { fewer than } 3 \text { days } \\
4 \text { days and more }\end{array}$ & $\begin{array}{l}101 \\
20\end{array}$ & $\begin{array}{l}83.6 \\
16.4\end{array}$ & $\begin{array}{c}26 \\
9\end{array}$ & $\begin{array}{l}74.0 \\
26.0\end{array}$ & $\begin{array}{c}14 \\
0\end{array}$ & $\begin{array}{l}96.8 \\
3.2\end{array}$ & $\begin{array}{l}84 \\
78\end{array}$ & $\begin{array}{l}52.0 \\
48.0\end{array}$ & $\begin{array}{c}26 \\
1\end{array}$ & $\begin{array}{c}98.1 \\
1.9\end{array}$ & $\begin{array}{l}4 \\
0\end{array}$ & $\begin{array}{c}95.0 \\
5.0\end{array}$ & $\begin{array}{l}9 \\
9\end{array}$ & $\begin{array}{l}52.1 \\
47.9\end{array}$ & $\begin{array}{c}115 \\
9\end{array}$ & $\begin{array}{l}92.6 \\
7.4\end{array}$ & 0.000 \\
\hline $\begin{array}{l}\text { Adults eat less to spare } \\
\text { food for children }\end{array}$ & $\begin{array}{l}\text { fewer than } 3 \text { days } \\
4 \text { days and more }\end{array}$ & $\begin{array}{c}104 \\
27\end{array}$ & $\begin{array}{l}79.3 \\
20.7\end{array}$ & $\begin{array}{l}32 \\
11\end{array}$ & $\begin{array}{l}74.8 \\
25.2\end{array}$ & $\begin{array}{c}20 \\
0\end{array}$ & $\begin{array}{c}98.8 \\
1.2\end{array}$ & $\begin{array}{l}58 \\
77\end{array}$ & $\begin{array}{l}42.8 \\
57.2\end{array}$ & $\begin{array}{c}25 \\
1\end{array}$ & $\begin{array}{c}98.0 \\
2.0\end{array}$ & $\begin{array}{l}1 \\
0\end{array}$ & $\begin{array}{l}100.0 \\
0.0\end{array}$ & $\begin{array}{c}0 \\
10\end{array}$ & $\begin{array}{c}4.6 \\
95.4\end{array}$ & $\begin{array}{l}97 \\
27\end{array}$ & $\begin{array}{l}78.4 \\
21.6\end{array}$ & 0.000 \\
\hline
\end{tabular}

\section{Appendix E}

Table A5. Sentences describing the household status during the previous 6 months.

\begin{tabular}{|c|c|c|c|c|c|c|c|c|}
\hline & & \multicolumn{2}{|c|}{ Overall } & \multicolumn{4}{|c|}{ Gender } & \multirow[b]{3}{*}{$p$-Value } \\
\hline & & & & & & & & \\
\hline & & \multicolumn{2}{|c|}{$\mathrm{N}(\%)$} & \multicolumn{2}{|c|}{$\mathbf{N}(\%)$} & \multicolumn{2}{|c|}{ N (\%) } & \\
\hline $\begin{array}{l}\text { Which of these sentences applies the most to the food eaten by } \\
\text { your household in the past } 6 \text { months? }\end{array}$ & $\begin{array}{l}\text { We had enough to eat of the kinds of food we wanted (quantity and quality) } \\
\text { We had enough to eat but not always the kinds of food we wanted (only quantity) } \\
\text { Sometimes we did not have enough to eat (quantity) } \\
\text { Often, we did not have enough to eat } \\
\text { Don't Know/Refuse to answer }\end{array}$ & $\begin{array}{c}128 \\
435 \\
446 \\
334 \\
45\end{array}$ & $\begin{array}{c}9.2 \\
31.3 \\
32.1 \\
24.1 \\
3.2\end{array}$ & $\begin{array}{l}78 \\
236 \\
236 \\
163 \\
16\end{array}$ & $\begin{array}{c}10.7 \\
32.4 \\
32.4 \\
22.4 \\
2.2\end{array}$ & $\begin{array}{c}50 \\
199 \\
210 \\
171 \\
29\end{array}$ & $\begin{array}{c}7.6 \\
30.2 \\
31.9 \\
25.9 \\
4.4\end{array}$ & 0.024 \\
\hline $\begin{array}{l}\text { In the last } 6 \text { months, was there a time when you were } \\
\text { concerned that you would run out of food for your household } \\
\text { for the next month? }\end{array}$ & $\begin{array}{l}\text { Don't Know/Refuse to answer } \\
\text { No } \\
\text { Yes }\end{array}$ & $\begin{array}{c}40 \\
138 \\
1210\end{array}$ & $\begin{array}{r}2.9 \\
9.9 \\
87.2\end{array}$ & $\begin{array}{l}21 \\
90 \\
618\end{array}$ & $\begin{array}{r}2.9 \\
12.3 \\
84.8\end{array}$ & $\begin{array}{l}19 \\
48 \\
592\end{array}$ & $\begin{array}{l}2.9 \\
7.3 \\
89.8\end{array}$ & 0.007 \\
\hline $\begin{array}{l}\text { Did the following statement apply to your household in the last } \\
6 \text { months? "The food that we bought was not enough and we } \\
\text { didn't have money to get more." }\end{array}$ & $\begin{array}{l}\text { Don't Know/Refuse to answer } \\
\text { No } \\
\text { Yes }\end{array}$ & $\begin{array}{c}51 \\
189 \\
1148\end{array}$ & $\begin{array}{c}3.7 \\
13.6 \\
82.7\end{array}$ & $\begin{array}{l}28 \\
115 \\
586\end{array}$ & $\begin{array}{r}3.8 \\
15.8 \\
80.4\end{array}$ & $\begin{array}{c}23 \\
74 \\
562\end{array}$ & $\begin{array}{l}3.5 \\
11.2 \\
85.3\end{array}$ & 0.041 \\
\hline $\begin{array}{c}\text { Are there any foods you feel your family does not eat } \\
\text { enough of? }\end{array}$ & $\begin{array}{c}\text { Don't Know/Refuse to answer } \\
\text { No } \\
\text { Yes }\end{array}$ & $\begin{array}{c}47 \\
160 \\
1181\end{array}$ & $\begin{array}{c}3.4 \\
11.5 \\
85.1\end{array}$ & $\begin{array}{l}24 \\
93 \\
612\end{array}$ & $\begin{array}{l}3.3 \\
12.8 \\
84.0\end{array}$ & $\begin{array}{c}23 \\
67 \\
569\end{array}$ & $\begin{array}{c}3.5 \\
10.2 \\
86.3\end{array}$ & 0.31 \\
\hline $\begin{array}{l}\text { In the past } 6 \text { months, did you or any other adult in your } \\
\text { household ever cut the size of your meal because there was not } \\
\text { enough food? }\end{array}$ & $\begin{array}{l}\text { Don't Know/Refuse to answer } \\
\text { No } \\
\text { Yes }\end{array}$ & $\begin{array}{c}63 \\
248 \\
1077\end{array}$ & $\begin{array}{c}4.5 \\
17.9 \\
77.6\end{array}$ & $\begin{array}{l}37 \\
155 \\
537\end{array}$ & $\begin{array}{r}5.1 \\
21.3 \\
73.7\end{array}$ & $\begin{array}{c}26 \\
93 \\
540\end{array}$ & $\begin{array}{l}3.9 \\
14.1 \\
81.9\end{array}$ & 0.001 \\
\hline $\begin{array}{l}\text { In the past } 6 \text { months, did you or any other adult ever skip a } \\
\text { meal because there was not enough food? }\end{array}$ & $\begin{array}{c}\text { Don't Know/Refuse to answer } \\
\text { No } \\
\text { Yes }\end{array}$ & $\begin{array}{l}64 \\
388 \\
936\end{array}$ & $\begin{array}{l}4.6 \\
28.0 \\
67.4\end{array}$ & $\begin{array}{l}31 \\
230 \\
468\end{array}$ & $\begin{array}{l}4.3 \\
31.6 \\
64.2\end{array}$ & $\begin{array}{l}33 \\
158 \\
468\end{array}$ & $\begin{array}{l}5.0 \\
24.0 \\
71.0\end{array}$ & 0.007 \\
\hline $\begin{array}{l}\text { In the past } 6 \text { months did you or any adult in your household } \\
\text { not eat for a whole day or go to bed hungry because there was } \\
\text { not enough food? }\end{array}$ & $\begin{array}{l}\text { Don't Know/Refuse to answer } \\
\text { No } \\
\text { Yes }\end{array}$ & $\begin{array}{l}64 \\
847 \\
477\end{array}$ & $\begin{array}{l}4.6 \\
61.0 \\
34.4\end{array}$ & $\begin{array}{l}34 \\
459 \\
236\end{array}$ & $\begin{array}{l}4.7 \\
63.0 \\
32.4\end{array}$ & $\begin{array}{l}30 \\
388 \\
241\end{array}$ & $\begin{array}{l}4.6 \\
58.9 \\
36.6\end{array}$ & 0.25 \\
\hline $\begin{array}{l}\text { During the last } 6 \text { months, was there a time when you or any } \\
\text { adult in your household were unable to eat healthy and } \\
\text { nutritious food because of a lack of money or other resources? }\end{array}$ & $\begin{array}{c}\text { Don't Know/Refuse to answer } \\
\text { No } \\
\text { Yes }\end{array}$ & $\begin{array}{c}45 \\
245 \\
1098\end{array}$ & $\begin{array}{c}3.2 \\
17.7 \\
79.1\end{array}$ & $\begin{array}{l}25 \\
154 \\
550\end{array}$ & $\begin{array}{l}3.4 \\
21.1 \\
75.4\end{array}$ & $\begin{array}{l}20 \\
91 \\
548\end{array}$ & $\begin{array}{l}3.0 \\
13.8 \\
83.2\end{array}$ & 0.001 \\
\hline $\begin{array}{l}\text { During the last } 6 \text { months, was there a time when you or any } \\
\text { adult in your household were hungry but did not eat because } \\
\text { there was not enough money or other resources for food? }\end{array}$ & $\begin{array}{l}\text { Don't Know/Refuse to answer } \\
\text { No } \\
\text { Yes }\end{array}$ & $\begin{array}{l}89 \\
641 \\
658\end{array}$ & $\begin{array}{l}6.4 \\
46.2 \\
47.4\end{array}$ & $\begin{array}{l}40 \\
370 \\
319\end{array}$ & $\begin{array}{r}5.5 \\
50.8 \\
43.8\end{array}$ & $\begin{array}{r}49 \\
271 \\
339\end{array}$ & $\begin{array}{l}7.4 \\
41.1 \\
51.4\end{array}$ & 0.001 \\
\hline $\begin{array}{l}\text { During the last } 6 \text { months, was there a time when you or any } \\
\text { adult in your household went without eating for a whole day } \\
\text { because of a lack of money or other resources? }\end{array}$ & $\begin{array}{l}\text { Don't Know/Refuse to answer } \\
\text { No } \\
\text { Yes }\end{array}$ & $\begin{array}{l}10 \\
829 \\
549\end{array}$ & $\begin{array}{l}0.7 \\
59.7 \\
39.6\end{array}$ & $\begin{array}{c}5 \\
455 \\
269\end{array}$ & $\begin{array}{l}0.7 \\
62.4 \\
36.9\end{array}$ & $\begin{array}{c}5 \\
374 \\
280\end{array}$ & $\begin{array}{l}0.8 \\
56.8 \\
42.5\end{array}$ & 0.099 \\
\hline
\end{tabular}

\section{References}

1. Food and Agriculture Organization of the United Nations (FAO); International Fund for Agricultural Development (IFAD); UNICEF; UN World Food Program (WFP); World Health Organization (WHO). The State of Food Security and Nutrition in the World 2020: Transforming Food Systems for Affordable Healthy Diets; FAO: Rome, Italy, 2020. [CrossRef]

2. Karasapan, O. Middle East Food Security Amid the COVID-19 Pandemic. Brookings. 14 July 2020. Available online: https://www. brookings.edu/blog/future-development/2020/07/14/middle-east-food-security-amid-the-covid-19-pandemic/ (accessed on 1 May 2021).

3. Worldbank. Population Total-Lebanon. 2020. Available online: https://data.worldbank.org/indicator/SP.POP.TOTL?locations= LB (accessed on 8 March 2021).

4. Food and Agriculture Organization (FAO). Food Security Indicators [Data Set]. Available online: http://www.fao.org/economic/ ess/essfs/essfadata/en/\#.VNoh153LfYg (accessed on 17 November 2014).

5. Lebanon's Food Insecurity and the Path Toward Agricultural Reform. Available online: https://carnegie-mec.org/2020/11/13 /lebanon-s-food-insecurity-and-path-toward-agricultural-reform-pub-83224 (accessed on 1 April 2021). 
6. Five Fundamentals to Keep Lebanon's Water Flowing. Available online: https:/ /www.iied.org/five-fundamentals-keep-lebanonwater-flowing (accessed on 30 January 2021).

7. World Health Organization. Lebanon Explosion 2020. Available online: https://www.who.int/docs/default-source/documents/ emergencies / who-leb-partners-update-18-august-2020.pdf?sfvrsn=820c93ad_4 (accessed on 1 March 2021).

8. Lebanon VAM Update on Food Price and Market Trends December 2020. Available online: https://docs.wfp.org/api/documents/ WFP-0000122981/download/ (accessed on 1 March 2021).

9. Paramastri, R.; Pratama, S.A.; Ho, D.K.N.; Purnamasari, S.D.; Mohammed, A.Z.; Galvin, C.J.; Hsu, Y.H.E.; Tanweer, A.; Humayun, A.; Househ, M.; et al. The Use of Mobile Applications to Improve Nutrition Behaviour: A Systematic Review. Taipei Medical University. Comp. Methods Programs Biomed. 2020, 192, 105459. Available online: https://tmu.pure.elsevier.com/en/publications/ the-use-of-mobile-applications-to-improve-nutrition-behaviour-a-s (accessed on 1 January 2021).

10. McKay, F.H.; Wright, A.; Shill, J.; Stephens, H.; Uccellini, M. Using health and Well-Being Apps for Behavior Change: A Systematic Search and Rating of Apps. JMIR Mhealth Uhealth 2019, 7, e11926. [CrossRef] [PubMed]

11. Mandracchia, F.; Llauradó, E.; Tarro, L.; Del Bas, J.M.; Valls, R.M.; Pedret, A.; Radeva, P.; Arola, L.; Solà, R.; Boqué, N. Potential Use of Mobile Phone Applications for Self-Monitoring and Increasing Daily Fruit and Vegetable Consumption: A Systematized Review. Nutrients 2019, 11, 686. [CrossRef] [PubMed]

12. Rusnak, S.; Charney, P. Position of the Academy of Nutrition and Dietetics: Nutrition Informatics. J. Acad. Nutr. Diet. 2019, 119, 1375-1382. [CrossRef] [PubMed]

13. International Telecommunication Union (ITU). Press Release. Available online: https://www.itu.int/en/mediacentre/Pages/20 19-PR19.aspx (accessed on 1 May 2021).

14. Chen, C.; Karvela, M.; Sohbati, M.; Shinawatra, T.; Toumazou, C. PERSON-Personalized Expert Recommendation System for Optimized Nutrition. IEEE Trans. Biomed. Circuits Syst. 2018, 12, 151-160. [CrossRef] [PubMed]

15. Norouzi, S.; Kamel Ghalibaf, A.; Sistani, S.; Banazadeh, V.; Keykhaei, F.; Zareishargh, P.; Amiri, F.; Nematy, M.; Etminani, K. A Mobile Application for Managing Diabetic Patients' Nutrition: A Food Recommender System. Arch. Iran. Med. 2018, 21, 466-472. [PubMed]

16. Ministry of Agriculture; FAO; Informing More Effective Humanitarian Action-REACH. Food Security and Livelihoods Assessment of Lebanese Host Communities: Assessment Report; Food and Agricultural Organisation of the United Nations (FAO): Hazmieh, Lebanon, 2015.

17. Sahyoun, N.R.; Nord, M.; Sassine, A.J.; Seyfert, K.; Hwalla, N.; Ghattas, H. Development and validation of an Arab family food security scale. J. Nutr. 2014, 144, 751-757. [CrossRef] [PubMed]

18. Sheikomar, O.B.; Dean, W.; Ghattas, H.; Sahyoun, N.R. Validity of the Food Insecurity Experience Scale (FIES) for Use in League of Arab States (LAS) and Characteristics of Food Insecure Individuals by the Human Development Index (HDI). Curr. Dev. Nutr. 2021, 5, nzab017. [CrossRef] [PubMed]

19. VAM Resource Centre. FCS—Food Consumption Score. Available online: https://resources.vam.wfp.org/data-analysis/ quantitative/food-security / fcs-food-consumption-score (accessed on 1 May 2021).

20. Maxwell, D.; Calwell, R. The Coping Strategy Index: Field Methods Manual, 2nd ed.; CARE Cooperative for Assistance and Relief Everywhere, Inc.: Geneva, Switzerland, 2008; Used by Permission.

21. Centers for Disease Control and Prevention (CDC). Epi Info. 2021. Available online: https://www.cdc.gov/epiinfo/index.html (accessed on 1 May 2021).

22. UNHCR-The UN Refugee Agency. Lebanon. Available online: https:/ / reporting.unhcr.org/lebanon (accessed on 27 July 2021).

23. UN World Food Programme. Syria mVAM Bulletin \#50: November 2020. Available online: https://reliefweb.int/report/syrianarab-republic/syria-mvam-bulletin-50-november-2020 (accessed on 1 May 2021).

24. UN World Food Programme. Palestine Annual Country Report 2019: Country Strategic Plan 2018-2022; UN World Food Program: Beirut, Lebanon, 2019.

25. UN World Food Programme. mVAM-VAM Vulnerability and Food Security Assessment, July-August 2020; World Bank Group: Beirut, Lebanon, 2020.

26. UN World Food Programme. Vulnerability Assessment of Syrian Refugees in Lebanon. 2017. Available online: https://www. wfp.org/publications / 2017-vulnerability-assessment-syrian-refugees-lebanon (accessed on 1 January 2021).

27. Ghattas, H.; Sassine, A.J.; Seyfert, K.; Nord, M.; Sahyoun, N.R. Food insecurity among Iraqi refugees living in Lebanon, 10 years after the invasion of Iraq: Data from a household survey. Br. J. Nutr. 2014, 112, 70-79. [CrossRef] [PubMed]

28. Ghattas, H.; Sassine, A.J.; Seyfert, K.; Nord, M.; Sahyoun, N.R. Prevalence and correlates of food insecurity among Palestinian refugees in Lebanon: Data from a household survey. PLoS ONE 2015, 10, e0130724. [CrossRef] [PubMed]

29. Jomaa, L.; Naja, F.; Kharroubi, S.; Hwalla, N. Prevalence and correlates of food insecurity among Lebanese households with children aged 4-18 years: Findings from a national cross-sectional study. Public Health Nutr. 2019, 22, 202-211. [CrossRef] [PubMed]

30. Sheikomar, O.B.; Wambogo, E.; Sahyoun, N.R.; Ghattas, H. Social determinants of food insecurity in the Arab Region: A comparative study. FASEB J. 2017, 31, 791.29. 
31. Omidvar, N.; Ahmadi, D.; Sinclair, K.; Melgar-Quiñonez, H. Food security in selected Middle East and North Africa (MENA) countries: An inter-country comparison. Food Secur. 2019, 11, 531-540. [CrossRef]

32. Global Food Security Cluster. COVID-19: Weeks 10 \& 11 Situation Update 1st-15th of June 2020. 2020. Available online: https:/ / fscluster.org/coronavirus/document/covid-19-weeks-10-11-situation-update (accessed on 1 May 2021).

33. UN World Food Programme. Assessing the Impact of the Economic and COVID-19 Crises in Lebanon (Round 2). 2020. Available online: https: / reliefweb.int/sites/reliefweb.int/files/resources/WFP-0000123200.pdf (accessed on 1 May 2021). 